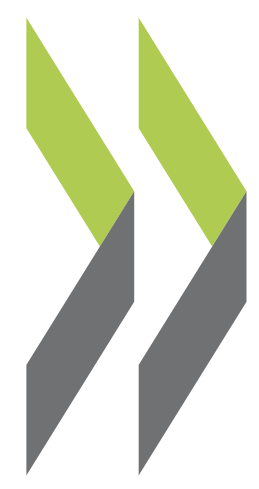

OECD Regional Development Working Papers 2013/05

Passing the Buck? Central and Sub-national Governments in Times of Fiscal Stress
Rudiger Ahrend, Marta Curto-Grau, Camila Vammalle 


\section{OECD REGIONAL DEVELOPMENT WORKING PAPERS}

This series is designed to make available to a wider readership selected studies on regional development issues prepared for use within the OECD. Authorship is usually collective, but principal authors are named. The papers are generally available only in their original language English or French with a summary in the other if available.

The opinions expressed in these papers are the sole responsibility of the author(s) and do not necessarily reflect those of the OECD or the governments of its member countries.

Comment on the series is welcome, and should be sent to either gov.contact@oecd.org or the Public Governance and Territorial Development Directorate, 2, rue André Pascal, 75775 PARIS CEDEX 16, France.

OECD Regional Development Working Papers are published on http://www.oecd.org/gov/regional/workingpapers

Applications for permission to reproduce or translate all or part of this material should be made to: OECD Publishing, rights@oecd.org or by fax 33145249930.

(C) OECD 2013 


\title{
PASSING THE BUCK? CENTRAL AND SUB-NATIONAL GOVERNMENTS IN TIMES OF FISCAL STRESS
}

\author{
Rudiger Ahrend, Marta Curto-Grau and Camila Vammalle ${ }^{1}$
}

The paper explores interrelations between the fiscal situation of sub-national and central governments, or - put differently - whether and how sub-national and central governments contribute to each other's fiscal difficulties. The first part of the paper examines sub-national government policies that may negatively affect the fiscal situation of the central government. Based on a new cross-country data-set at the level of individual regions, it examines structural factors that increase the probability of sub-national entities accumulating amounts of debt that may ultimately turn out to be unsustainable. The underlying idea is to explore to what degree such debt levels could result from moral hazard-driven behaviour at the regional level. The second part of the paper examines whether and how national governments hand the burden of fiscal adjustment down to sub-national levels, mainly looking at examples from the wave of fiscal adjustments in the wake of the 2007-09 global financial crisis.

JEL Classification: H70, H74, H81, H12

Keywords: public debt, sub-national governments, bailouts, fiscal stress

1. The authors are indebted to David Bartolini, Hansjoerg Blöchliger, Claire Charbit, Norbert Gaillard, Mario Marcel and Teresa Ter-Minassian, Bill Tompson, as well as the participants at the 2012 joint IMF-OECD Fiscal Workshop for useful comments. The authors would like to thank Claudia Hulbert for first rate research assistance. The views expressed here are those of the authors, and do not necessarily reflect those of the OECD or its member countries. 


\section{INTRODUCTION}

This paper explores interrelations between the fiscal situation of sub-national and central governments, or - put differently - whether and how sub-national and central governments contribute to each other's fiscal difficulties, in particular in times of fiscal stress.

The first part of the paper examines sub-national government policies that may negatively affect the fiscal situation of the central government. It explores how and to what extent some sub-national governments accumulate levels of debt that could be considered as risky. Under adverse economic circumstances such entities may then require (and often obtain) implicit or explicit central or sub-national bailouts to prevent a default. A descriptive section examines current levels of sub-national debt directly at the level of individual regions, thereby allowing for a better understanding of the potential risk from high sub-national debt than could not be gained from aggregate sub-national data only. This descriptive section also looks at the evolution of sub-national government debt markets in recent years. An econometric section then examines structural factors - both at the regional and national level - that increase the probability of sub-national entities accumulating amounts of debt that may ultimately turn out to be unsustainable. The underlying idea is to explore to what degree such debt levels could result from moral hazard-driven behaviour at the regional level. Existing cross-country studies usually only look at national averages of sub-national debt, thereby not capturing the potentially large dispersion within countries.

The second part of the paper examines whether and how national governments hand the burden of fiscal adjustment down to sub-national levels. This discussion takes into account that margins for adjustment are generally smaller at the sub-national level. The analysis is mainly based on examples from the wave of fiscal adjustments in the wake of the 2007-09 global financial crisis. It also briefly looks at the impact of recent sovereign downgrades on regional governments.

Key results are:

- While aggregate levels of sub-national debt remain generally low, there is large variation within countries, with debt reaching fairly high levels for some sub-national entities.

- In general, sub-national debt levels seem to be explained both by sub-national debt-service capacities, as well as bailout expectations and political economy variables.

- In particular, proxies for higher debt-service capacities, such as larger sub-national power over their revenue or expenditure levels, are reflected in higher sub-national debt.

- With respect to bailout expectations, regions with larger possibilities to influence national policies appear to generally have higher debt. This indicates that either their greater capacity to extract concessions from the central government would be reflected in a higher perceived probability of a bailout, or that the more limited capacity of the central government to discipline an individual region is directly associated with higher regional debt.

- Regional governments that have the same political orientation than the central government have a tendency to have higher debt levels.

- While central government actions affect the fiscal situation of sub-national governments in many different and often substantial ways, on the currently available (limited) information it is impossible to say whether during and in the aftermath of the global financial crisis the burden of adjustment has been shared in an even fashion. 


\section{HOW SUB-NATIONAL POLICIES AFFECT CENTRAL GOVERNMENTS}

The overarching theme of this section is to explore mechanisms of how sub-national governments can negatively affect the fiscal position of the central government, before looking for evidence of such behaviour in recent years. It first presents descriptive evidence for OECD countries about levels of subnational debt and its evolution during the global financial crisis and its aftermath, as well as recent developments in SNG debt markets. The section then examines whether regional debt levels can be explained by regions' debt-service capacities, or are rather driven by moral hazard as regions accumulate overly large debt levels in expectation of being bailed out by central governments.

\subsection{Developments in sub-national debt}

\subsubsection{Potential risks of sub-national government debt}

Debt creates various externalities across levels of government (see e.g. Blöchliger, 2011, for a more detailed discussion). First, the sustainability of debt is determined by actions of all levels of governments. Even modest increases in debt by a large number of government entities may significantly increase general government debt, thereby affecting budget balances and potentially interest rates on public debt. The dynamics of this common pool problem are even more pertinent if discontinuities or threshold effects are present, i.e. if there are large increases in interest rates or decreases in growth rates, once a certain general government debt level is exceeded. Second, financial problems of one, even small, SNG can have large repercussions on the functioning of markets for municipal and regional bonds and lead to a rise in risk premia. Spreading fear of a general malaise at the sub-national level may become self-fulfilling if it renders SNGs' access to private financing at sustainable interest rates impossible. Third, SNGs often own public enterprises whose debt is not accounted for in the national accounts, but represents contingent liabilities. In most countries, SNGs are owners or co-owners of infrastructure companies for water, energy, transport and the like. In several countries, states or regions are holders of public banks which also provide credit to public enterprises or municipalities, thus exacerbating risks. ${ }^{2}$ Finally, in most countries the CG is held politically responsible for SNG debt, often taking on the form of implicit or explicit bailout guarantees. ${ }^{3}$ SNGs expecting a bailout may then engage in unsustainable debt policy, thereby potentially increasing general government debt.

\subsubsection{Average levels of sub-national debt}

Average levels of sub-national debt are not particularly alarming. Sub-national debt as a share of overall GDP is generally low (Figure 1), and with the exception of a handful of mainly federal countries usually presents only a small share of overall government debt. ${ }^{4}$ In 2011, SNG debt accounted for an average $16 \%$ of total public debt, with the sub-national debt share ranging from roughly $1 \%$ in Greece to $53 \%$ in Canada.

2. Defaults of state-owned banks have led to protracted financial difficulties for individual sub-national governments in Germany, Switzerland and the United States.

3. For example, Danish municipalities receive specific financial help from central government if they get into financial difficulties, and are put under administrative control (Mau, 2011). In Germany, the constitutional court ruled that the federal government had to help out two Länder (states) which were in financial distress.

4. SNGs are usually subject to tight fiscal rules. In many countries, they can only borrow to finance public investment, and/or face ceilings to their debt or debt service (e.g. maximum levels of annuities as a share of operating revenues). 
Figure 1. Debt as a share of GDP, 2011

Sub-national and central government debt as a share of national GDP

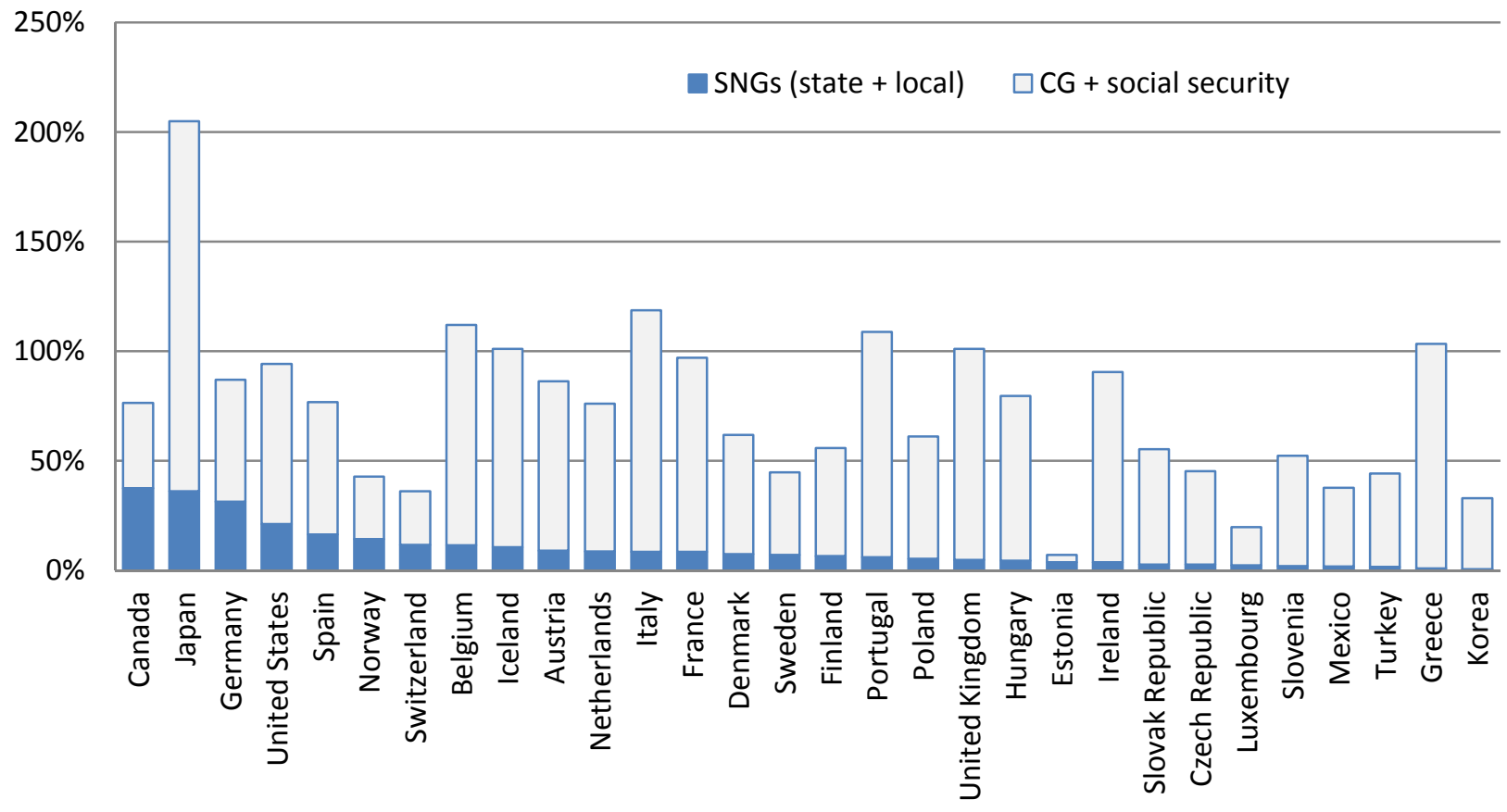

Note: Data for Canada, Estonia, Ireland, Japan and the US are from 2010, and for Mexico and Switzerland from 2009. "State" refers to the level immediately below the central government. For federal countries, this might be defined as "region", "state", "province" or "Länder", depending on the country. The local level refers to municipal authorities.

Sub-national debt relative to GDP may, however, not be the most relevant measure for assessing debt sustainability, as it may not well capture SNGs' capacity to raise resources. The revenue base of SNGs is not only comparatively smaller than that of central governments, but their autonomy to increase revenues is usually limited, with little or no power over tax rates or tax bases and high reliance on transfers. ${ }^{5}$ So unless sub-national debt is considered as guaranteed by the central government, measuring sub-national debt as a share of revenues rather than of GDP would appear more appropriate for assessing sustainability.

Sub-national debt as a share of revenues is indeed relatively high in some cases, but in general it remains well below comparable figures for central government debt. For almost all OECD countries in the sample, the debt of central governments as a share of their revenues is above $100 \%$, and for roughly half of them it is close to or above $200 \%$. In contrast, for SNG debt the corresponding ratios are generally below and often well below - 100\%, the exception being the German "Länder", Canadian provinces, US states, and Norwegian localities.

\footnotetext{
5. For a measure of SNG tax autonomy, see: Fiscal Decentralisation Database (www.oecd.org/document/32/0,3746,en_2649_37427_47467040_1_1_1_37427,00.html) and Blöchliger and King (2006).
} 
Figure 2. Public debt as a share of revenues, 2010

Debt as a share of the revenues of the respective entity

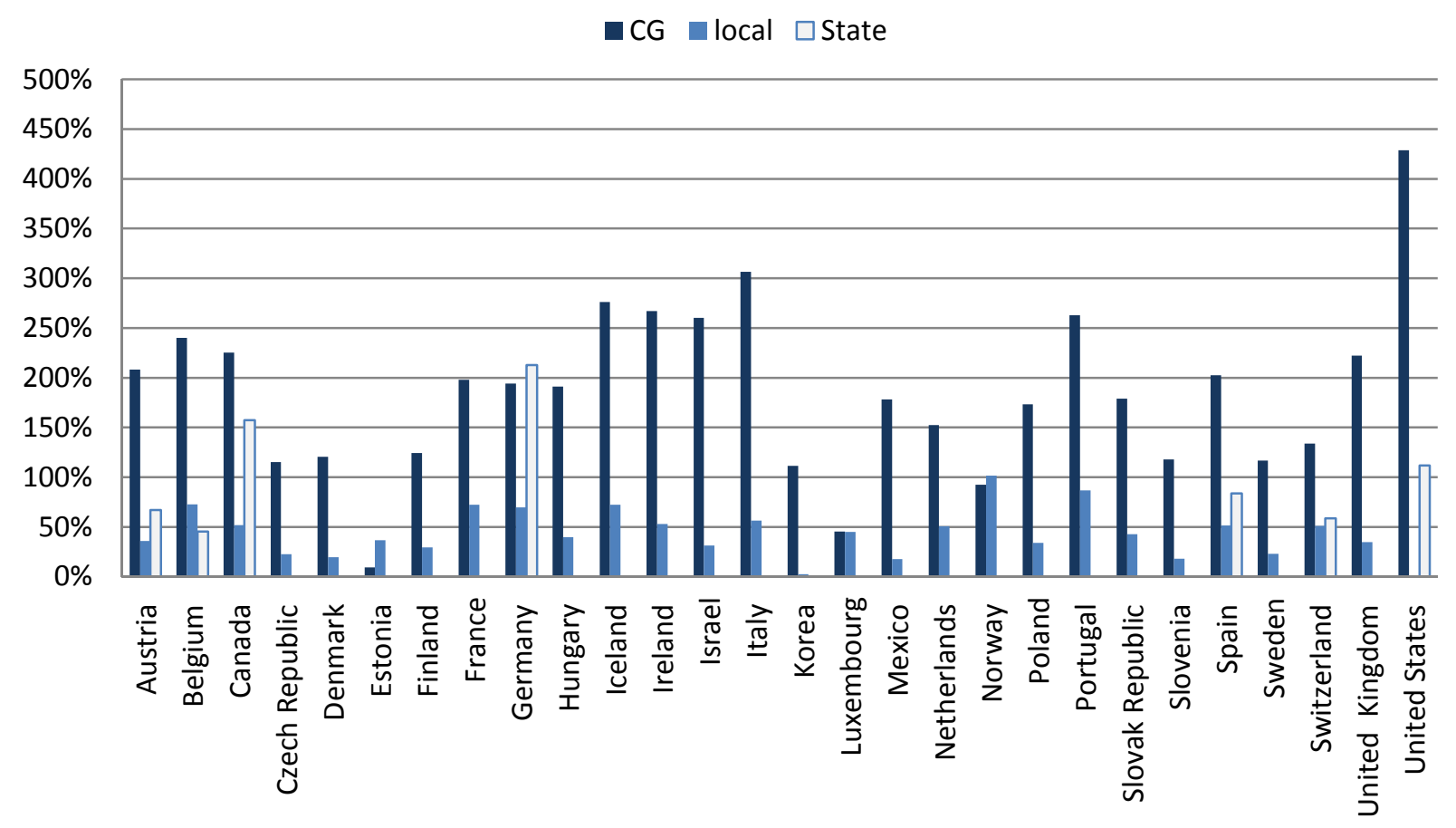

Note: "State" refers to the level immediately below the central government. For federal countries, this might be defined as "region", "state", "province" or "Länder", depending on the country. The local level refers to municipal authorities. When no precisions are given (i.e. for non federal countries), all the SNGs are aggregated in the local measure. Data is non-consolidated. Data for Korea, Mexico and Switzerland for 2009.

\subsubsection{Dispersion of sub-national debt within countries}

While the currently available data allows assessing the level of dispersion for only ten OECD countries, this sub-sample already shows fairly high levels of dispersion within countries. The extreme case is Germany where, already prior to the global financial crisis, the Land of Bremen had accumulated debt almost $4 \frac{1}{2}$ times its revenues. In addition to some German Länder, some Canadian provinces also show relatively elevated debt-to-revenue levels. In contrast, the level of sub-national debt prior to the global financial crisis was not particularly high in Spain. 
Figure 3. Dispersion of SNG debt, 2007

Sub-national debt as a share of sub-national revenues

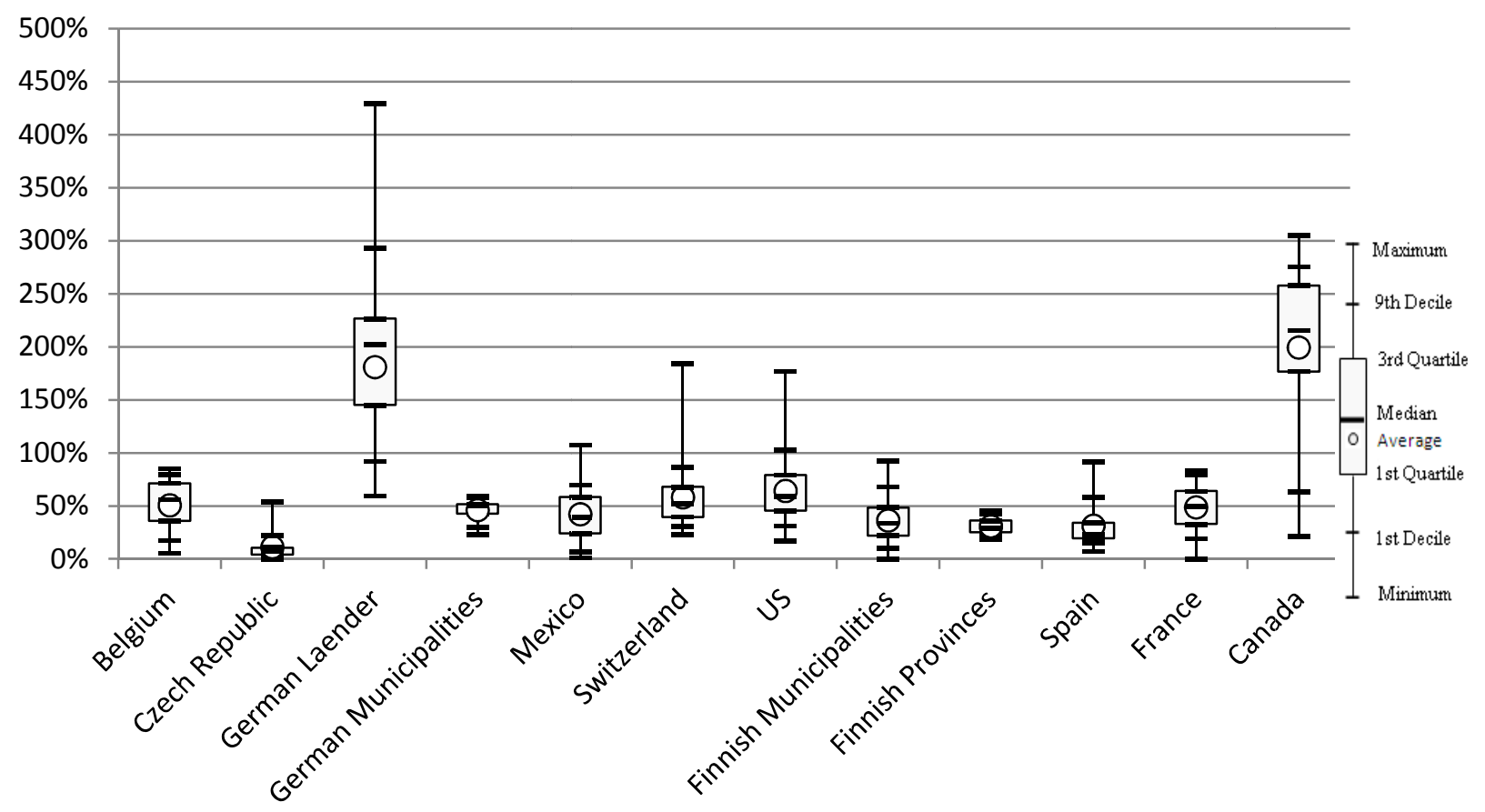

Note: With the exception of Finnish and German municipalities, the presented data refer to the level immediately below the central government (TL2). For federal countries, this might be defined as "region", "state", "province" or "Länder", depending on the country.

Source: Authors' calculations based on responses to OECD questionnaire and data from publicly available official data.

\subsubsection{SNG finances during the 2007-09 global financial crisis and in its aftermath}

After 2007, the financial situation of SNGs' deteriorated due to a scissors effect, i.e. decreased tax revenues and increased demand for social services. This led to an increase in SNGs' deficits and debts, though increases often remained moderate due to higher transfers from CGs under large stimulus packages implemented as countercyclical policy measures during the crisis (Blöchliger et al. 2010). For many SNGs the situation dramatically deteriorated starting 2010 as these additional transfers disappeared with many countries implementing national consolidation policies. On average, SNG deficits (as a share of revenues) increased from less than $1 \%$ in 2007 to somewhat above 5\% in 2010, while the average SNG debt-torevenue ratio rose from $45 \%$ to $54 \%$ during the same period. While increases in SNG debt have been substantial from the perspective of a number of sub-national governments, resulting increases in aggregated sub-national debt have remained limited from a macroeconomic perspective in most cases (SNG debt increased from an average 10\% of GDP in 2007 to $13 \%$ in 2010). 
Figure 4. Evolution of SNG deficits as a share of SNG revenues (2007-2010)

Sub-national debt as a share of sub-national revenues, percentage point change 2007-2010

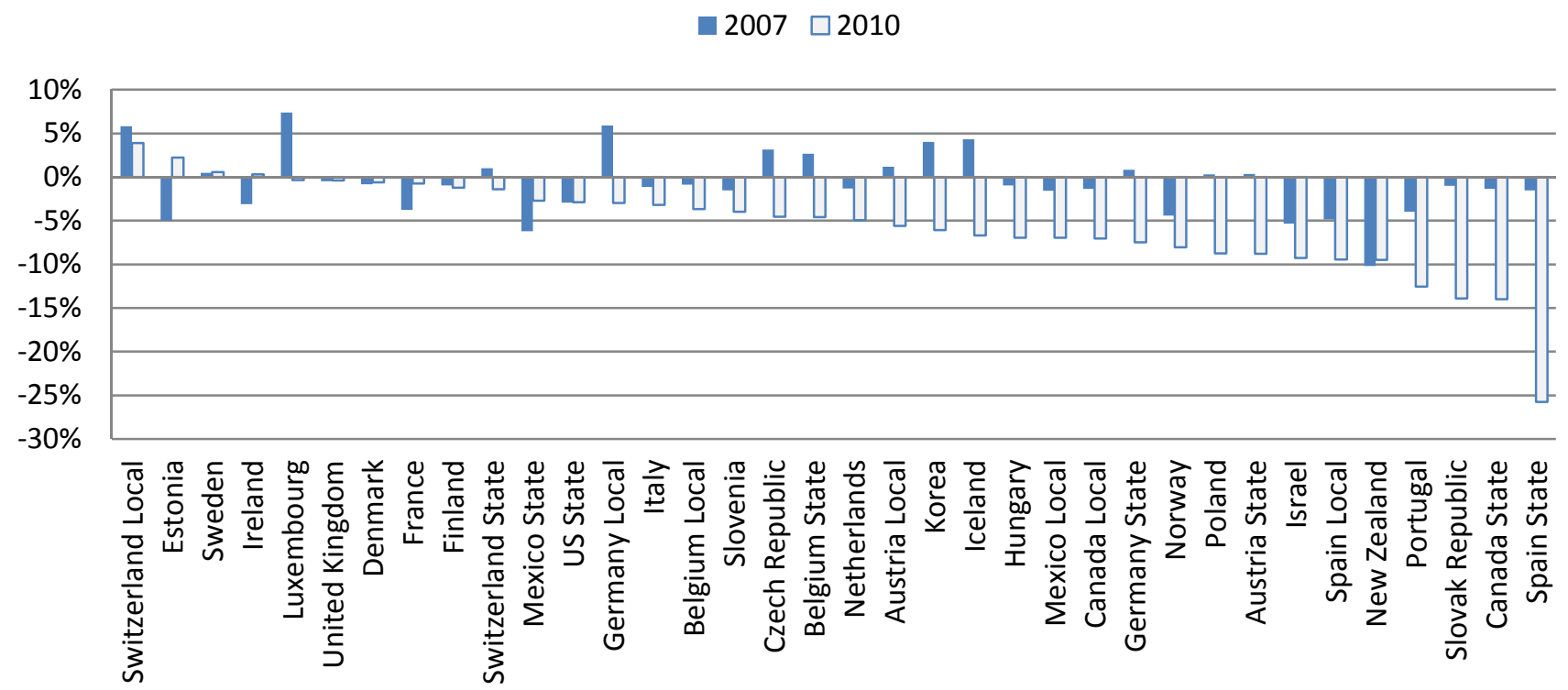

Note: "State" refers to the level immediately below the central government. For federal countries, this might be defined as "region", "state", "province" or "Länder", depending on the country. The local level refers to municipal authorities. When no precisions are given (i.e. for non federal countries), all the SNGs are aggregated in the same measure.

Source: Authors' calculations based on OECD National Accounts and OECD Fiscal Decentralisation Database

The dispersion of SNG debt within countries did not generally increase during the global financial crisis and in its direct aftermath. It increased in some countries, but somewhat declined in others, possibly due to the fact that more indebted regions undertook greater efforts. Relatively large increases occurred in Mexico and in Germany (the debt of the Land of Bremen further rising). ${ }^{6}$ In Spain and Belgium, fairly large increases in SNG debt were relatively uniform and did not result in notably larger dispersion across regions within the country.

6. Bremen and four other Länder are now receiving central government help to reduce deficits as long as they comply with the new framework of the "Schuldenbremse" (debt break). 
Figure 5. Evolution of SNG debt (2007-2010)

Sub-national debt as a share of sub-national revenues, state level

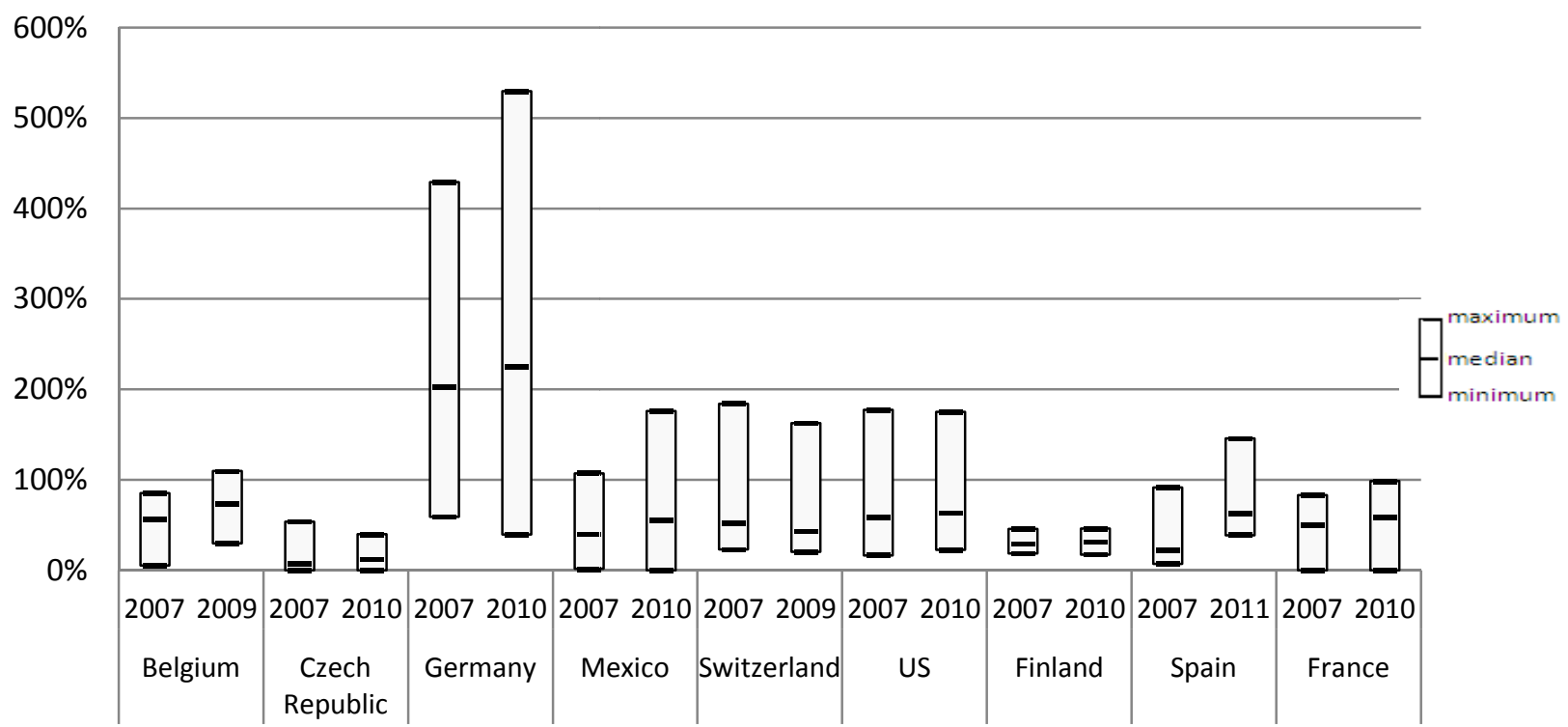

Note: The presented data refer to the level immediately below the central government (TL2). For federal countries, this might be defined as "region", "state", "province" or "Länder", depending on the country.

Source: Authors' calculations based on responses to OECD questionnaire and data from publicly available official data.

It is noteworthy that even after the increases of recent years, neither the level nor the regional dispersion of Spain's sub-national debt is particularly large. It would seem that, at least during periods of financial turmoil, financial markets question the sustainability of sub-national government debt at much lower levels than that of central government debt. This would imply that sub-national debt in an individual region/locality can create negative spillovers to other regions/localities or to its central government even at levels at which the debt from the Central government would likely not be considered as problematic. Even at comparatively low levels of debt, the fiscal situation of SNGs' may thus affect the evaluation of CG's financial position: rising interest rates or the need for bailing out regions may threaten the credibility of CGs' consolidation plans. In Spain, for example, the failure of the regions ${ }^{7}$ to comply with their 2011 deficit targets was cited by Moody's as one of the factors that contributed to its downgrade of Spanish government debt in February 2012.8

\subsubsection{Financial market monitoring of SNG debt}

During the 2007-09 global financial crisis, and in particular in the wake of the fall of Lehman Brothers in October 2008, credit flows to SNGs perceived as riskier borrowers were temporarily disrupted. In contrast, SNGs with top ratings benefited from a flight to quality and continued to tap international bond markets without major difficulties (Vammalle et al., 2011). Since 2011, this trend has been reinforced: yields of high rated bonds were lower in 2012 than in 2007, while yields of lower rated SNGs have reached

7. Autonomous communities are the regional/state level of government in Spain.

8. "Moody's expects the budget deficits for the general government sector to be above target both this year and next. In particular, Moody's continues to have serious concerns regarding the funding situation of the regional governments and their ability to reduce their budget deficits according to targets." ("Moody's downgrades Spain's government bond ratings to A1, negative outlook"; Global Credit Research, 18 October 2011). 
record highs (Figure 6). The fall in the yield of A rated bonds in January 2012 is due to the downgrades of Andalucía, Baleares, Cataluña and Madrid from the A to the BBB categories. Financial markets had been pricing yields of these securities above those that remained in the A category since the beginning of 2009.

Figure 6. SNG bond yields by rating (2007-2012)

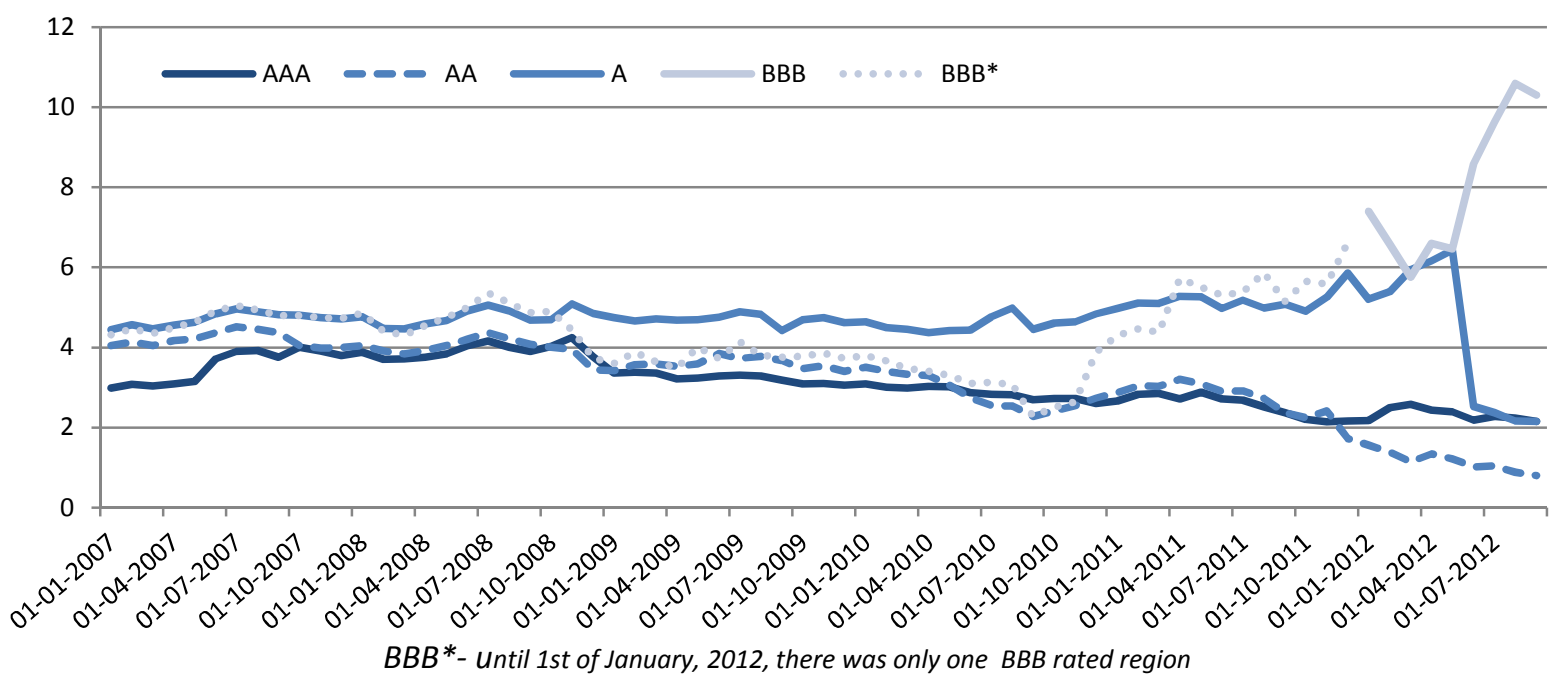

Source: Authors' calculations based on Datastream.

Similarly, spreads between the best and the worst borrower within countries increased after the Lehman collapse in October 2008 (Figure 7). After an initial increase from less than 200 basis points in 2007 to about 300 basis points in 2009, spreads remained rather stable until the end of 2011. At that time, growing doubts about the capacity of Spanish and Italian SNGs to consolidate, and their frequent downgrades by rating agencies resulted in surging spreads, reaching more than 1000 basis points in 2012 for Spain.

Figure 7. Range of variation of yields

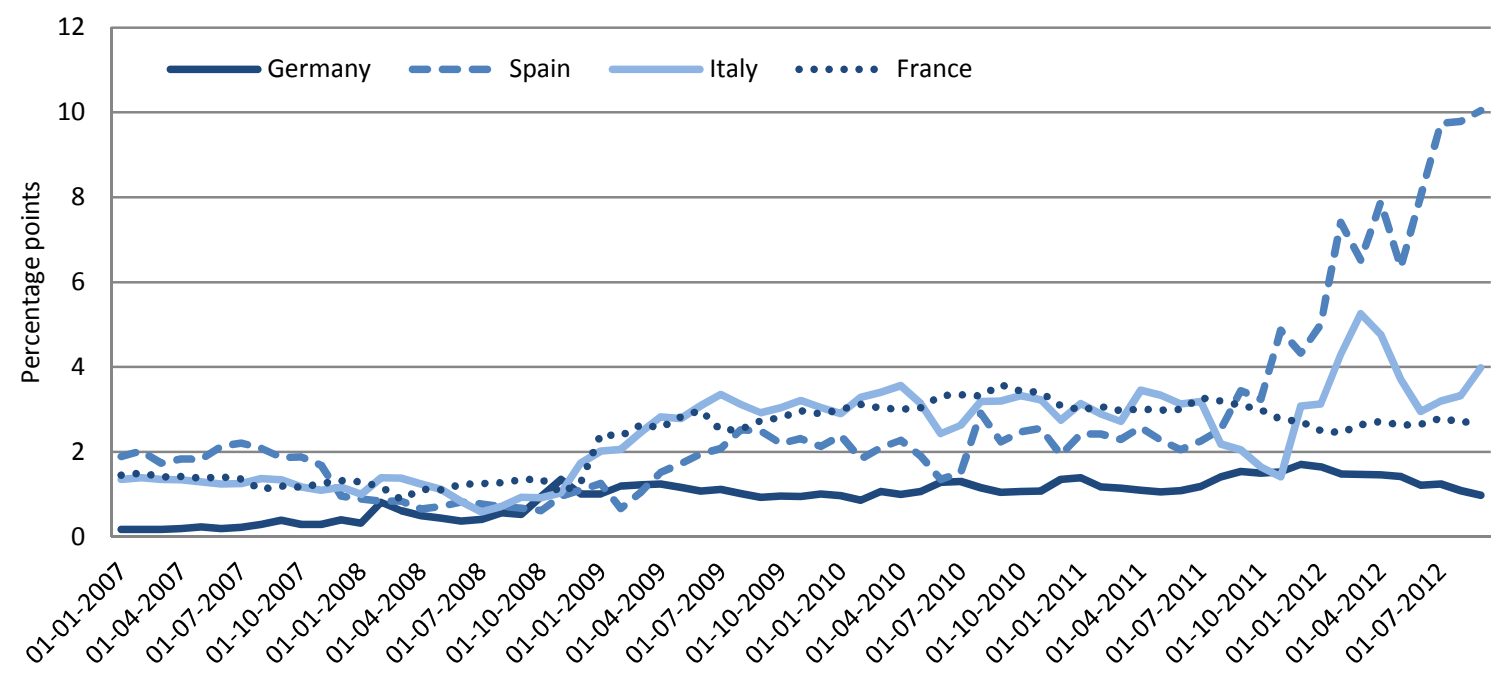

Source: Authors' calculations based on Datastream. 
Plotting SNG yields against their respective ratings unsurprisingly shows that lower ratings come with higher yields. More interestingly, this correlation has evolved strongly between 2007 and 2012 with investors increasingly requiring higher markups for lower rated bonds (Figure 8). This raises questions about whether financial markets have been pricing sub-national risk efficiently.

Figure 8. SNG yields and ratings (2007, 2010 and 2012)

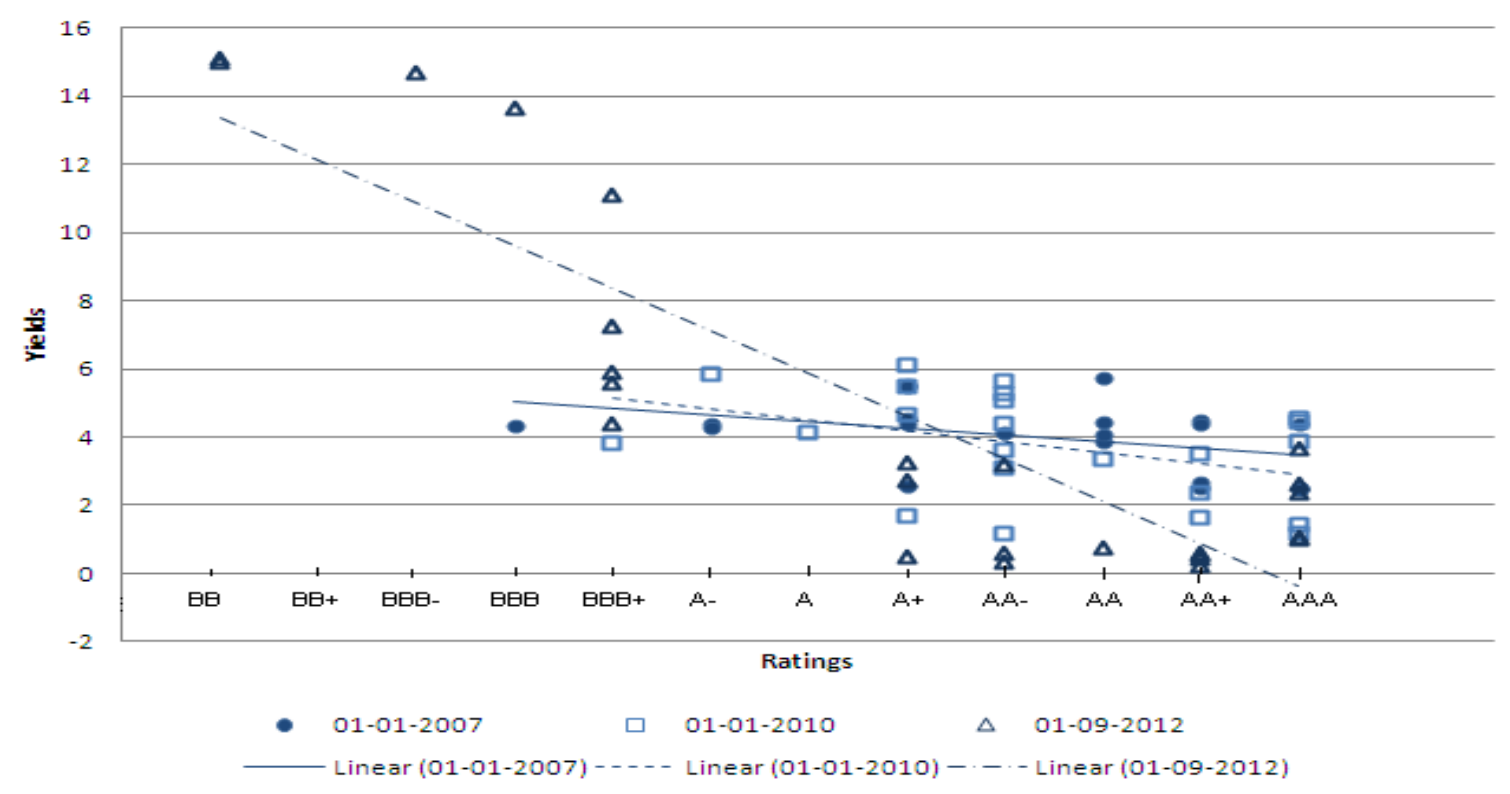

Source: Authors' calculations based on data from Datastream and S\&P.

\subsection{Structural determinants of SNG's debt}

Problems of debt sustainability at the sub-national level that lead to requests for bailouts can occur when a region suffers an exceptionally large shock (e.g. a natural disaster), in which case help to the concerned region arguably presents a form of potentially desirable risk-sharing mechanism. However, bailout requests can also arise as a consequence of moral hazard as regional governments or their creditors take the possibility of a bailout into account, potentially resulting in levels of regional debt that may ultimately require a bailout to avoid default. Understanding whether levels of regional debt are mainly driven by moral hazard or factors such as debt servicing capacity is hence key for exploring the potential of individual regions' policies to negatively affect central government's fiscal situations.

\subsubsection{A short review of the literature}

In spite of the increased policy focus on the fiscal situation of sub-national governments in recent years, little attention has been devoted to the empirical study of the determinants of sub-national borrowing. In the following literature review, potential determinants of sub-national governments' debt levels are grouped into three main categories. First, regional debt levels could be influenced by expectations of a central government bailout, should the need arise. Second, the level of sub-national borrowing may be expected to depend upon a region's debt servicing capacity. Third, political factors such as the political orientation and alignment of regional governments may also influence debt levels of regions. Given the small amount of work on the determinants of SNGs debt, the following literature review refers not only to studies that evaluate fiscal discipline, in terms of either debt or deficits, at the subnational level (using essentially aggregated data), but to a large degree also on studies at the national level. 


\section{The role of bailout expectations}

An important peculiarity of SNGs is the fact that they are part of a larger entity that provides them with external resources and monitors them to a greater or lesser extent. In a situation of economic stress and under a soft budget constraint, regions may expect central governments to bail them out with additional resources. This clearly poses a moral hazard problem as sub-national governments may take into account the probability of receiving bailout transfers and set their debt level inefficiently high, as described and tested by Garcia-Milà a et al. (2002) for Spanish regions.

The likelihood of being bailed out, in turn, depends on several factors. First, according to the "too big to fail" hypothesis (Wildasin 1997) the size of a sub-national jurisdiction, in terms of population, has a positive impact on the probability of receiving a bailout because the negative externalities derived from a sub-national default affect a larger amount of inhabitants. This hypothesis, though, has found no empirical support. If any, the empirical evidence points towards the opposite effect. As noted by von Hagen et al. (2000), the two German states bailed out in the 1990s were the smallest ones in the West German federation and, in Italy, smaller municipalities and regions seem to have a higher willingness to request bailouts. The reason for these observations may simply be that central governments may be more willing to bail out smaller regions as costs are lower.

Alternatively, following the "too sensitive to fail" hypothesis (von Hagen et al., 2000, Bordignon and Turati, 2009, Sorribas-Navarro, 2011) the real scope of the externality is not the population size but the extent to which SNGs provide key public services such as health, education or social services. Third, regions may be "too financially weak to fail" when large vertical imbalances exist. For example, central governments may feel obliged to bail out regions that strongly depend on SG transfers as such regions may not have enough capacity to raise necessary resources by themselves. Although regions with large fiscal imbalances tend to be subject to borrowing restrictions (Eichengreen and von Hagen, 1996), in practice this does not seem to prevent the need for bailouts.

Legal borrowing constraints might have opposite consequences on SNG debt levels. On the one side, tight fiscal rules are set to restrain governments from over-indebtedness. The empirical evidence on this matter, however, is inconclusive. Some studies find evidence that balanced budget rules have negative impacts on budget balance deficits (e.g. Poterba, 1994, and Bohn and Inman, 1996, both studies looking at a panel of US states). Other literature concludes that fiscal rules do not play an important role in ensuring better fiscal performance (Escolano et al., 2012). In this case, a plausible explanation stated by Escolano et $a l$. is that sub-national fiscal rules might not be sufficient to ensure good performance when spending mandates of sub-national governments are underfunded. In any case, an analysis of the impact of fiscal rules on fiscal balances risks to suffer from a severe endogeneity problem because, as highlighted by the recent economic crisis, fiscal rules are often the response to deteriorated fiscal balances rather than the cause. Grembi et al. (2011) get around the endogeneity problem by using the fact that in 2001 Italy relaxed fiscal rules for municipalities below 5000 inhabitants as a quasi-experimental research design. Their estimates show that, on average, this relaxation of fiscal rules triggered a shift from balanced budgets to a 2 percent deficit.

On the other side, borrowing restrictions may be easily eluded in a situation where the dependence on transfers is high, responsibilities are not clearly allocated, or accountability levels are low. An illustrative example can be found in Italy (von Hagen et al., 2000). Italian local public finances suffered a deep crisis during the 1970s and 1980s due to a tax reform introduced in 1972-73, which reduced drastically the fiscal autonomy of municipalities and made them extremely dependent on central government grants. In this context, von Hagen et al. argue, expenditures kept rising and the inability of local governments to raise revenues and cover expenses led them to borrow large amounts of funds from commercial banks. The consequence was that municipalities approached bankruptcy and had to be bailed out by the central 
governments through an increase in transfers in 1978 (a measure introduced jointly with stricter debt limits). The unintended outcome was that over-indebted municipalities were de facto compensated for their bad financial performance through larger transfers. So, high reliance on transfers might generate a common pool problem as SNGs do not fully bear the cost of overspending and this can translate into high levels of debt.

A last factor that can influence the probabilities of receiving a bailout is political strength. As noted by Rodden (2002) "when constitutionally or politically constrained central governments take on heavy cofinancing obligations they often cannot credibly commit to ignore fiscal problems of lower-level governments." Thus, the higher the degree of political pressure a regional government can exert on central governments, the more likely it would be to obtain a bailout if needed.

\section{The role of regional debt-servicing capacity}

Besides the probability of being bailed out, another crucial factor for obtaining debt financing is a region's own capacity to repay its debt, i.e. its debt servicing capacity. Such fiscal capacity is often associated with the government's "operating surplus" (see Lewis 2003) or a revenue concept that includes tax revenues and block grants adjusted for some indicator of spending needs (see Borge et al., 2008). Alternatively, debt service capacity can also be linked to fiscal decentralisation, the idea being that a larger capacity to raise resources or to control spending increases a region's potential to serve debt. While the literature typically looks at links between fiscal decentralisation and fiscal performance from angles that do not make a specific link to debt service capacity, the empirical results from that literature are still relevant for the question explored in this paper.

Some studies find fiscal decentralisation to improve fiscal performance of sub-national units. For instance, a study of Swiss cantons shows that in times of crisis more decentralised cantons, in political, fiscal or administrative terms, have lower deficits (Freitag and Vater, 2008). ${ }^{9}$ Rodden's (2002) analysis of a cross-section of several OECD, developing and transition countries concludes that long-term balanced budgets are more likely to occur when sub-national governments have both taxing and borrowing autonomy (or - if they do not have these powers - when tight rules are imposed on them by central governments). Baskaran (2010), using a panel of 17 OECD countries, finds that expenditure decentralization helps reducing the aggregate level of sub-national borrowing, while tax decentralisation and vertical fiscal imbalances have a statistically insignificant effect. ${ }^{10}$ Other studies, however, argue that when SNGs can tax and spend at their own discretion, coordination problems may arise, leading to large deficits (de Mello, 2000). Similarly, based on Norwegian local government data, Tovmo (2007) explores the impact of centralisation (i.e. the existence of a "centralised administrative procedure" or a "centralised political process") ${ }^{11}$ on deficits. He finds that deficits are lower under a centralised system and ascribes this result to a considerable reduction of common-pool problems in the decision-making process. All in all, the considerable divergence in results appears to a large degree driven by differences in methodology or variables used to measure fiscal decentralisation (i.e. expenditure or revenue decentralisation, etc.).

9. Political decentralization refers to the degree of cantonal municipal autonomy (information extracted from a survey); fiscal decentralization is equal to cantonal tax revenue/(cantonal+municipal tax revenue); administrative decentralization is the average number of persons per municipality in a canton.

10. Defined as the sub-national revenue coming from taxes for which sub-national governments determine rates and/or define bases as share of general government tax revenue.

11. In a centralized administrative procedure it is a chief administrator who initially presents a budget proposal that may be changed by an executive board. The centralized political process is similar to the previous concept but in contrast, the initial proposal is discussed between the executive board and the chief administrator. See Tovmo (2007) for further details. 


\section{Other political determinants of $S N G$ debt}

Another perspective to take into consideration is the link between (party) politics and debt levels, an issue examined by the political economy literature. A well known approach within this strand of literature is the "weak government" hypothesis, introduced by Roubini and Sachs (1989a), which assumes that management problems arising from fragmented political power foster fiscal imbalances. Roubini and Sachs study central government budget deficits across OECD countries during the 1975-85 period and find that political weakness (short average tenure of government or a multi-party ruling coalition) increases deficits.

Others point towards ideological differences between governing parties as factors explaining borrowing policies. In this sense, left-wing governments are sometimes seen as having a bias towards large public spending and higher debt levels, whereas right-wing governments would have a lower preference for public expenditures. The empirical evidence on this issue is, however, mixed. For instance, Roubini and Sachs (1989b) show that OECD countries ruled by a left-wing party have higher deficits. In contrast, Borrelli and Royed (1995) find empirical support that budget deficits are higher when a right-wing party is governing. Some other papers, for instance Blais et al. (1993), find no evidence on the influence of ideology on public spending or debt. Seitz (2000), in one of the rare studies that explore differences in deficits by looking at the regional level, uses individual data on German Länder and concludes that on average the ideology of regional governments does not have a significant effect on SNG deficits.

The political (or electoral) business cycle (Nordhaus, 1975) has also been identified as one of the determinants of public spending, budget deficits, taxation and other policy instruments. According to this view, politicians act in an opportunistic and/or tactical manner when elections approach. Alesina et al. (1993), for example, examine the electoral manipulation of policy instruments for a set of OECD countries and find - amongst other results - that fiscal deficits are larger in the year preceding an election. In the run up to elections, yardstick competition driven spending mimicking across jurisdictions is also likely to occur for Italian municipalities, as shown by Bartolini and Santolini (2012).

Lastly, the political or partisan alignment between regional and central governments could also have an impact on sub-national spending or borrowing. Khemani (2002), for instance, shows that in India spending and deficits of sub-national governments that belong to the same political party as the central government are lower than when such an alignment does not exist. In contrast, Arulampalam et al. (2009) find that US states that in the last state election were both aligned with the central government and swing states received higher transfers than unaligned or non-swing states.

\subsubsection{Empirical approach}

The objective of this empirical section is to explore the determinants of sub-national borrowing by using disaggregated debt data at the individual regional level from different countries. To the best knowledge of the authors, this is the first study that uses a cross-country panel containing data on the fiscal situation of individual regions. The availability of data at the regional level limits the study to six countries: Germany, Finland, Canada, France, the US, and Spain, which results in a combined dataset of over 130 regions within both federal and unitary countries. For Germany, Canada, France, the US, and Spain large regions (TL2) are considered. ${ }^{12}$ For Finland, the data used correspond to small regions (TL3). The period under study is 2002-2009. The data has been collected from national budgets on countries' official government websites, national statistical offices, as well as from answers to a questionnaire sent to

12. That is German Länder, Canadian provinces, French regions, US states and Spanish comunidades autónomas. 
delegates of the OECD Network on Fiscal Relations across Levels of Government and to those of the OECD Working Party of Senior Budget Officials.

To assess empirically the importance of the above-mentioned factors in determining debt levels, both a pooled OLS approach and, when sufficient time variation allows it, a linear panel data model with region fixed effects are used. When the lack of sufficient time variation would render results obtained from regional fixed-effects regressions meaningless, country-year fixed effects are instead used in pooled OLS regressions. In addition, a simple OLS regression is also run (for 2005). The baseline (OLS) model is as follows:

Debt $_{\mathrm{it}}=\alpha+\beta$ BailoutExpectations $_{\mathrm{it}}+\mu$ DebtServiceCapacity $_{\mathrm{it}}+\gamma$ PoliticalFactors $_{\mathrm{it}}+\delta \mathrm{X}_{\mathrm{it}}+\varepsilon_{\mathrm{it}}$ Eq (1)

where Debt $_{i t}$ refers to the sub-national debt-to-revenues ratio in region $i$ at time $t$; BailoutExpectations contains a set of variables that are linked to the probability of regions to be bailed out;

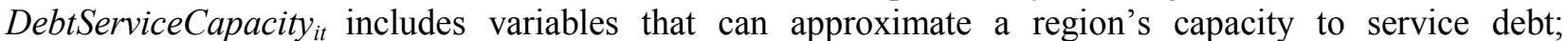
PoliticalFactors $s_{i t}$ includes other political variables that may influence debt levels; $X_{i t}$ is a vector containing several control variables, namely a region's unemployment rate as well as its GDP growth rate to control for business cycle effects; and $\varepsilon_{\text {it }}$ is the error term. In the models where region, country and/or country-year fixed-effects are included, $\alpha$ is replaced by a region-specific constant $\alpha_{i}, \alpha_{j}$ or $\alpha_{j t}$, respectively. The idiosyncratic error term in the linear panel-data model may suffer from a serial correlation problem as unobservable factors that one cannot control for may affect debt while potentially being correlated over time within regions. ${ }^{13}$ Moreover, in any year, residuals may be correlated within a country. Therefore, in the pooled and region fixed-effects regressions, the errors are two-way clustered at the region and countryyear level. As a robustness check, regressions are also run using the debt-to GDP ratio instead of the debtto-revenue ratio. Moreover, to ensure that results are not driven by possible cyclical fluctuations in revenues, all regressions are re-run using a debt-to-revenue ratio calculated using revenues where cyclical volatility has been smoothed through a standard HP filtering process with a smoothing factor, $\lambda$, of 6.25 .

\section{Bailout expectations}

Based on the literature on bailouts reviewed in the previous section, the variables that are subsumed under BailoutExpectations in Eq.1 can be grouped into four subcategories:

- Too-big-to-fail hypothesis

A simple variable to assess this hypothesis is the regional population as a share of total national population (Population share).

- Provision of key spending

To approximate the extent to which regional governments are responsible for key public spending, the variable Key spending is constructed as regional per capita spending on education, social services and health divided by the general government per capita spending on these items.

For a more detailed evaluation, the variable is further disaggregated into education spending (Education) and health plus social services spending (Health). ${ }^{14}$

13. The Wooldrige (2002) test for autocorrelation confirms that the null hypothesis of no serial correlation is rejected $(\mathrm{F}$-test $=20.165$, $\mathrm{p}$-value $=0.0000)$.

14. The aggregation level at which most national budgets present their data does not allow us to distinguish between social and health spending. 
- Vertical imbalances ("Too weak to fail")

Vertical imbalances are proxied through the degree of transfer dependence from central governments, measured as the share of transfers in total regional revenues (Transfer dependence). In order to reduce endogeneity problems, as transfers could in fact be an implicit bailout, the variable is lagged.

- Political strength at central level

To assess the degree of political pressure that regional governments can exert on the central government the "shared-rule" indicator from the Regional Authority Index (RAI) database is used. ${ }^{15}$ This indicator evaluates the degree of authority that a regional government has over the representatives of the country as a whole, and therefore captures the potential of regions to extract concessions from the central government. The "shared rule" index takes, for example, into account the extent to which regional representatives co-determine national legislation or the distribution of tax revenues. Alternatively, this indicator can also be seen as a measure of the degree to which the central government can discipline an individual SNG (with higher values indicating less possibility to discipline). The indicator takes values from 0 to 9 (from decreasing to increasing authority) and is labelled as Shared rule in the regressions.

\section{Capacity to service debt}

The variables listed as FiscalCapacity in Eq. 1 mainly include measures for a regions' potential to raise revenues, or determine its expenditures (i.e. to cut them should the need arise) ${ }^{16}$

- Potential to raise revenues

One measure of regional governments' potential to raise revenues (and therefore, to repay their debt as long as there is political willingness) are indicators of regional (expected) income. Examples used here are regions' GDP per capita and potential GDP growth (named GDPpc and Potential growth, respectively). Potential growth of regional GDP is calculated as the trend component from a HP filtering process. ${ }^{17}$

Apart from the economic potential for levying taxes, a region's capacity to service debt depends also on its capacity to actually transform its economic potential into revenues. One measure of that is the actual taxes a region obtains, measured as a share of their total revenues (Tax revenue). ${ }^{18}$

Another measure of revenue-raising capacity is the degree to which a region can decide itself on taxes. This is measured through the fiscal autonomy indicator from the previously mentioned RAI database. This indicator measures "the extent to which a regional government can independently tax its population" (the variable is labelled as Taxing autonomy).

15. Data source: www.unc.edu/ gwmarks/data_ra.php. The RAI is an indicator of the authority of regional governments in 42 countries.

16. While important, this is not further pursued as the relatively limited time dimension of the sample does not allow for very meaningful measures of volatility/variance, which is consistent with regressions that were tentatively run not providing any results.

17. The trend is computed as in Ravn and Uhlig (2002), that is, with a smoothing factor $\lambda$ of 6.25.

18. In some instances regional tax revenue includes taxes which are shared with other levels of government and upon the level of which a region may have no direct influence. However, even in such a case, tax revenues would be expected to be more stable in the sense that the moral claim of a region on such revenues is certainly higher than for transfers, for example. This in turn should also increase the willingness of lenders to lend to the region. 
- Potential to reduce spending

To measure the political capacity to determine spending, an indicator, referred to as Spending Autonomy, is compiled by aggregating the two relevant variables from the RAI database. This indicator can also be seen as a partial proxy for the rigidity of expenditures. ${ }^{19}$ More precisely, this indicator is obtained by aggregating the following two indicators:

a) Institutional depth index: measures the extent to which a region is endowed with an independent legislature and executive.

b) Policy scope index: the range of policies for which a regional government is responsible (e.g. whether SNGs have authoritative competencies in economic policy or welfare state policy?).

The Spending Autonomy indicator is also interacted with a variable that measures actual regional spending (Expenditure), as one would expect that the capacity to determine spending has more impact when one actually has higher expenditure levels. The expenditure level is computed as regional spending as a share of regional GDP.

\section{Political Factors}

The last category introduced in Eq.1, PoliticalFactors includes two different political variables: $:^{20}$

\section{- Political orientation}

To test whether ideological biases (i.e. whether regional governments are left or right) affect debt levels, a dummy variable (Political orientation) accounting for this fact is introduced as an explanatory variable. ${ }^{21}$

\section{- Political alignment}

To assess the possibility that the alignment between central and regional governments affects debt levels, a binary variable indicating whether the regional and central government have the same political orientation is used (Political alignment). Further, if the central government has a majority of seats in the parliament, its degree of freedom to take action is higher and this, in turn, could potentially increase its bias to favour aligned regional governments. Thus, the Political alignment variable is interacted with another dummy variable that is equal to one if the central government has more than $50 \%$ of parliamentary seats (variable labelled Majority).

The exact definition and the key characteristics of the variables discussed above are summarised in Table 1. Beyond these variables, there obviously are some other factors that could influence regional debt levels, such as the fiscal strength of the national government, or the volatility of a region's revenues. However, a larger data sample would be needed to explore the impact of these factors in a meaningful

19. Another possibility to measure expenditure rigidity in a region would be to look at the actual volatility or variance of its expenditures, in particular in periods of nationwide fiscal restraint. While important, this is not further pursued as the relatively limited time dimension of the sample does not allow for very meaningful measures of volatility/variance, which is consistent with not obtaining any results for this weak variable in tentative regressions.

20. Unfortunately, the previously mentioned "weak government" hypothesis cannot be tested due to a lack of information at the regional level regarding coalition governments. Nor it is feasible to test for the political business cycle hypothesis.

21. Data on the ideological orientation of regional governments is available for all countries of the studied panel with the exception of Finland. 
way. ${ }^{22}$ Another factor that could affect debt levels is the transparency of sub-national financial management. A number of countries have not managed to unify accounting rules across levels of government, publish audited sub-national accounts with substantial delays, or with many items off-balance. However, at this stage, the data required to explore these issues are not available.

Table 1. Variable descriptions and summary statistics

\begin{tabular}{|c|c|c|}
\hline Variable & Description & $\begin{array}{c}\text { Mean } \\
\text { (SD) }\end{array}$ \\
\hline Population share & Regional population/National population & $\begin{array}{c}0.04 \\
(0.06)\end{array}$ \\
\hline Key spending & $\begin{array}{l}\text { Regional Education+Health+Social services spending pc/National } \\
\text { Education+Health+Social services spending pc }\end{array}$ & $\begin{array}{c}0.33 \\
(0.20)\end{array}$ \\
\hline Education & Regional Education spending pc/National Education spending pc & $\begin{array}{c}0.61 \\
(0.29)\end{array}$ \\
\hline Health & $\begin{array}{l}\text { Regional spending on health and social services pc/National spending on health } \\
\text { and social services pc }\end{array}$ & $\begin{array}{l}0.25 \\
(0.19)\end{array}$ \\
\hline Transfer dependence & Transfers received/ Total regional revenues & $\begin{array}{c}0.31 \\
(0.17)\end{array}$ \\
\hline Shared rule & $\begin{array}{l}\text { Shared rule indicator comprised in the Regional Authority Index. It measures the } \\
\text { degree of authority that a regional government has over representatives at central } \\
\text { level }\end{array}$ & $\begin{array}{l}3.65 \\
(3.07)\end{array}$ \\
\hline Potential growth & $\begin{array}{l}\text { Potential growth of regional GDP is calculated as the trend component from a HP } \\
\text { filtering process }\end{array}$ & 0.02 \\
\hline$G D P p c$ & Regional GDP (PPP) in thousand \$US / Population & $\begin{array}{c}33.10 \\
(10.54)\end{array}$ \\
\hline Taxing autonomy & $\begin{array}{l}\text { Fiscal autonomy indicator from the Regional Authority Index (measuring the } \\
\text { extent to which a regional government can independently tax its population) }\end{array}$ & $\begin{array}{c}2.62 \\
(1.51)\end{array}$ \\
\hline Spending autonomy & $\begin{array}{l}\text { Composite indicator adding up two indices from the Regional Authority Index, } \\
\text { namely Institutional depth (the extent to which a region is endowed with an } \\
\text { independent legislature and executive) and Policy Scope (the range of policies for } \\
\text { which a regional government is responsible) }\end{array}$ & $\begin{array}{c}9.20 \\
(1.50)\end{array}$ \\
\hline Expenditure & Regional spending/Regional GDP & $\begin{array}{c}0.14 \\
(0.10)\end{array}$ \\
\hline Political orientation & $\begin{array}{l}\text { Binary variable equal to one if the regional government is left-wing oriented, } 0 \\
\text { otherwise }\end{array}$ & $\begin{array}{c}0.53 \\
(0.50)\end{array}$ \\
\hline Political alignment & $\begin{array}{l}\text { Binary variable equal to one if the regional government and the central } \\
\text { government have the same political orientation }\end{array}$ & $\begin{array}{c}0.12 \\
(0.32)\end{array}$ \\
\hline GDP growth & Growth rate of nominal regional GDP & $\begin{array}{c}0.04 \\
(0.04)\end{array}$ \\
\hline Unemployment & Unemployment rate & $\begin{array}{c}0.08 \\
(0.04)\end{array}$ \\
\hline Tax revenue & Regional tax revenues/ Regional total revenues & $\begin{array}{c}0.48 \\
(0.17) \\
\end{array}$ \\
\hline
\end{tabular}

22. The relatively limited time dimension of the sample does not allow for very meaningful measures of volatility/variance, which is consistent with not obtaining any results for this weak variable in tentative regressions. The fiscal strength of the central government, having no regional variation, would simply be sucked up in the country fixed effects. 


\subsubsection{Results $^{23}$}

This section provides empirical evidence for the previously stated hypotheses, i.e. it presents the results from estimating how the variables proxying for the probability of a bailout, the region's capacity to service debt, or the political orientation of a region's leadership affect sub-national debt levels.

\section{Bailout expectations}

For the panel of countries considered the empirical analysis presents evidence that moral hazard plays a role in determining sub-national debt levels. This evidence about the role of opportunistic behaviour in the formation of debt comes on top of the possibility of what may be called a "permanent bail-out", i.e. central government paying for spending overruns in the year they form through increased transfers.

More precisely, the analysis finds some evidence that political strength of regions at the national level is related to higher levels of regional debt. This indicates that regions with a stronger bargaining power vis$a$-vis the central government, which presumably would increase their probability of obtaining a bailout should such a need arise, have higher debt. Or, put differently, regions for which the central government's disciplining ability is lower have higher debt. In contrast, the empirical analysis provides no empirical evidence for the hypothesis that either high shares of politically sensitive regional spending or "vertical imbalances", i.e. a large share of transfers in regional revenues, are related to higher debt. It also provides no evidence that large "too big to fail" regions have higher debt.

- The coefficient associated with the regional population share is insignificant in the regressions, providing no empirical support for the "too big to fail" hypothesis (Table 2). This is consistent with an absence of empirical support for the "too big to fail" hypothesis in the literature.

Table 2. Too big to fail hypothesis

\begin{tabular}{lccc}
\hline \hline & $(1)$ & $(2)$ & $(3)$ \\
\hline & OLS & Pooled OLS & Pooled OLS \\
\hline Population share & & & \\
& 0.11 & 0.04 & 0.01 \\
Controls: & $(0.73)$ & $(0.77)$ & $(0.78)$ \\
Unemployment & & & \\
& 1.87 & 1.04 & 0.86 \\
GDP growth & $(1.46)$ & $(1.28)$ & $(1.57)$ \\
& -1.85 & -0.78 & -1.17 \\
Constant & $(1.60)$ & $(0.65)$ & $(0.70)$ \\
& $1.90^{* * *}$ & $1.93 * * *$ & $1.83 * * *$ \\
Observations & $(0.23)$ & $(0.29)$ & $(0.24)$ \\
R-squared & 134 & 1021 & 1021 \\
Controls & 0.72 & 0.67 & 0.68 \\
Country fixed-effects & $\mathrm{Y}$ & $\mathrm{Y}$ & $\mathrm{Y}$ \\
Time fixed-effects & $\mathrm{Y}$ & $\mathrm{Y}$ & $\mathrm{Y}$ \\
Region fixed-effects & $\mathrm{N}$ & $\mathrm{Y}$ & $\mathrm{Y}$ \\
Country $\times$ time fixed-effects & $\mathrm{N}$ & $\mathrm{N}$ & $\mathrm{N}$ \\
\hline
\end{tabular}

Note: In all pooled and region FE regressions, errors are two-way clustered at the region and country-year level.

23. Results are qualitatively similar when using the debt-over-GDP ratio or the debt-over-smoothed revenues ratio instead of the debt-over-revenues ratio. 
- Table 3 indicates that sub-national debt levels are clearly not increasing with key spending (both on education or health and social services). This is incompatible with the "too sensitive to fail" hypothesis. ${ }^{24}$

Table 3. Too sensitive to fail hypothesis

\begin{tabular}{|c|c|c|c|c|c|c|c|c|c|}
\hline & (1) & $(2)$ & (3) & (4) & (5) & (6) & (7) & (8) & $(9)$ \\
\hline & OLS & OLS & OLS & $\begin{array}{c}\text { Pooled } \\
\text { OLS }\end{array}$ & $\begin{array}{c}\text { Pooled } \\
\text { OLS }\end{array}$ & $\begin{array}{c}\text { Pooled } \\
\text { OLS }\end{array}$ & $\begin{array}{c}\text { Region } \\
\text { FE }\end{array}$ & $\begin{array}{c}\text { Region } \\
\text { FE }\end{array}$ & $\begin{array}{l}\text { Region } \\
\text { FE }\end{array}$ \\
\hline Key spending & $\begin{array}{l}-0.65 \\
(0.60)\end{array}$ & & & $\begin{array}{l}-0.70 \\
(0.83)\end{array}$ & & & $\begin{array}{l}-1.10^{*} \\
(0.47)\end{array}$ & & \\
\hline Education & & $\begin{array}{l}-0.62 \\
(0.32)\end{array}$ & & & $\begin{array}{l}-0.64 \\
(0.37)\end{array}$ & & & $\begin{array}{c}-0.52^{*} \\
(0.21)\end{array}$ & \\
\hline Health & & & $\begin{array}{l}-0.00 \\
(0.67) \\
\end{array}$ & & & $\begin{array}{c}0.06 \\
(0.93) \\
\end{array}$ & & & $\begin{array}{l}-0.50 \\
(0.28) \\
\end{array}$ \\
\hline Observations & 132 & 132 & 132 & 935 & 935 & 935 & 935 & 935 & 935 \\
\hline R-squared & 0.73 & 0.73 & 0.72 & 0.678 & 0.687 & 0.674 & 0.97 & 0.97 & 0.969 \\
\hline Region FE & $\mathrm{N}$ & $\mathrm{N}$ & $\mathrm{N}$ & $\mathrm{N}$ & $\mathrm{N}$ & $\mathrm{N}$ & $\mathrm{Y}$ & $\mathrm{Y}$ & $\mathrm{Y}$ \\
\hline
\end{tabular}

- Larger vertical imbalances seem to be related with lower debt levels (see coefficients of transfer dependence, Table 4, Columns 1-3), but this could in large part be driven by endogeneity. Even though, this is incompatible with the prediction of the "too weak to fail" hypothesis.

- The political strength of regional governments at the central level (Shared rule variable) is positive and statistically significant in the simple and pooled OLS regressions (Table 4, Columns $5-7),{ }^{25}$ even when controlling for country-year fixed effects. The size of the coefficient remains relatively robust when country fixed effects are introduced, but looses statistical significance. This probably reflects that the variance on the Political scope indicators is relatively smaller within than across countries, implying that the introduction of country fixed effects reduces the precision at which coefficients are estimated. All in all, this presents econometric evidence that the higher the bargaining power of regional governments, the higher their level of debt, with higher debt plausibly driven by the greater probability of obtaining a bailout if requested or lower capacities of the central government to discipline a region. The coefficient of the Shared rule variable indicates that the debt-to-revenue ratio is roughly 15 percentage points higher with each additional point in the "shared rule" indicator.

24. The statistical significance of some of the presented results is not robust when controlling for transfers received by regional governments, but coefficients generally remain negative. All in all, this presents still fairly strong evidence that the postulated hypothesis is unlikely to hold.

25. The lack of almost any time variation in this variable does not allow the use of region fixed effects. 
Table 4. Vertical imbalances and political strength at central level

\begin{tabular}{|c|c|c|c|c|c|c|c|c|c|}
\hline & $(1)$ & $(2)$ & $(3)$ & $(4)$ & $(5)$ & $(6)$ & $(7)$ & $(8)$ & $(9)$ \\
\hline & OLS & $\begin{array}{c}\text { Pooled } \\
\text { OLS }\end{array}$ & $\begin{array}{c}\text { Pooled } \\
\text { OLS }\end{array}$ & OLS & $\begin{array}{c}\text { Pooled } \\
\text { OLS }\end{array}$ & $\begin{array}{c}\text { Pooled } \\
\text { OLS }\end{array}$ & OLS & $\begin{array}{c}\text { Pooled } \\
\text { OLS }\end{array}$ & $\begin{array}{c}\text { Pooled } \\
\text { OLS }\end{array}$ \\
\hline $\begin{array}{l}\text { Transfer } \\
\text { dependence }_{t-1}\end{array}$ & $\begin{array}{c}-1.01 * * \\
(0.34)\end{array}$ & $\begin{array}{l}-0.95 * \\
(0.42)\end{array}$ & $\begin{array}{l}-1.02 * \\
(0.45)\end{array}$ & & & & & & \\
\hline Shared rule & & & & $\begin{array}{c}0.10 \\
(0.07)\end{array}$ & $\begin{array}{c}0.09 \\
(0.11)\end{array}$ & $\begin{array}{c}0.09 \\
(0.11)\end{array}$ & $\begin{array}{c}0.15 * * * \\
(0.02)\end{array}$ & $\begin{array}{c}0.15^{* * * *} \\
(0.02)\end{array}$ & $\begin{array}{c}0.14 * * \\
(0.05)\end{array}$ \\
\hline Observations & 134 & 967 & 967 & 134 & 1021 & 1021 & 134 & 1021 & 1021 \\
\hline R-squared & 0.74 & 0.69 & 0.70 & 0.73 & 0.67 & 0.68 & 0.49 & 0.40 & 0.64 \\
\hline Region fixed-effects & $\mathrm{N}$ & $\mathrm{N}$ & $\mathrm{N}$ & $\mathrm{N}$ & $\mathrm{N}$ & $\mathrm{N}$ & $\mathrm{N}$ & $\mathrm{N}$ & $\mathrm{N}$ \\
\hline Country $\times$ time FE & $\mathrm{N}$ & $\mathrm{N}$ & $\mathrm{Y}$ & $\mathrm{N}$ & $\mathrm{N}$ & $\mathrm{Y}$ & $\mathrm{N}$ & $\mathrm{N}$ & $\mathrm{Y}$ \\
\hline
\end{tabular}

Note: In all pooled and region fixed-effects regressions, errors are two-way clustered at the region and country-year level. Control variables as in Table 2 are included in all regressions, as are country fixed effects (except from regressions in columns 7-9). In the pooled and region fixed-effects regressions, time fixed-effects are equally included.

\section{Debt servicing capacity}

Sub-national debt levels are found to also depend on sub-national debt-service capacities. In particular, proxies for debt service capacities such as larger sub-national power over their revenue or expenditure levels are reflected in higher sub-national debt.

- No evidence is found that per capita GDP or potential GDP are related to debt levels (Table 5).

Table 5. Economic potential

\begin{tabular}{|c|c|c|c|c|c|c|}
\hline & $\begin{array}{c}\text { (1) } \\
\text { OLS }\end{array}$ & $\begin{array}{c}(2) \\
\text { Pooled OLS }\end{array}$ & $\begin{array}{c}(3) \\
\text { Pooled OLS }\end{array}$ & $\begin{array}{l}(4) \\
\text { OLS }\end{array}$ & $\begin{array}{c}(5) \\
\text { Pooled OLS }\end{array}$ & $\begin{array}{c}(6) \\
\text { Pooled OLS }\end{array}$ \\
\hline$G D P p c$ & $\begin{array}{c}0.01 \\
(0.01)\end{array}$ & $\begin{array}{c}0.01 \\
(0.01)\end{array}$ & $\begin{array}{c}0.01 \\
(0.01)\end{array}$ & & & \\
\hline Potential GDP growth & & & & $\begin{array}{l}-4.94 \\
(4.45)\end{array}$ & $\begin{array}{l}-3.06 \\
(1.82)\end{array}$ & $\begin{array}{l}-3.09 \\
(1.97)\end{array}$ \\
\hline Observations & 134 & 1021 & 1021 & 123 & 944 & 944 \\
\hline R-squared & 0.73 & 0.67 & 0.68 & 0.72 & 0.65 & 0.66 \\
\hline Region fixed-effects & $\mathrm{N}$ & $\mathrm{N}$ & $\mathrm{N}$ & $\mathrm{N}$ & $\mathrm{N}$ & $\mathrm{N}$ \\
\hline Country $\times$ time fixed-effects & $\mathrm{N}$ & $\mathrm{N}$ & Y & $\mathrm{N}$ & $\mathrm{N}$ & $\mathrm{Y}$ \\
\hline
\end{tabular}

Note: In all pooled and region fixed-effects regressions, errors are two-way clustered at the region and country-year level. Control variables as in Table 2 are included in all regressions, as are country fixed effects. In the pooled and region fixed-effects regressions, time fixed-effects are equally included.

- The degree of regional taxing autonomy is found to be an important determinant of sub-national borrowing. The results presented in Table 6, Column 2, would e.g. indicate that a 1 point increase in the taxing autonomy indicator increases debt levels by somewhere around 45 percentage points (close to a $60 \%$ increase for an average region) ${ }^{26}$. This result is in line with de Mello (2000), who finds that sub-national tax autonomy worsens the fiscal position (measured by the fiscal deficit to

26. This relation, however, does not need to be linear as it could be the case that once debt levels reach a high threshold, the capacity of servicing debt no longer suffices to obtain further borrowing. To test this idea a quadratic term of the Taxing autonomy variable is included (see Table A1 in the Annex).The OLS estimations suggest that the relation could be indeed non-linear (as the coefficient of the quadratic term is negative) but this result is not robust to the inclusion of region fixed-effects. 
GDP) of SNG. ${ }^{27}$ The results in Table 6 also suggest that the capacity of SNGs to raise tax revenues positively affects sub-national levels of debt (Columns 4-6). On average, an increase of 10 percentage point in the share of tax revenues raises debt levels by around 7-8 percentage points (a more than $10 \%$ increase for the average region). Moreover, when an interaction term between the Taxing autonomy variable and the share of tax revenues is included, the overall effect of a region's taxing autonomy is larger (Columns 7-9). This suggests that larger taxing autonomy has a larger impact on debt when regions have higher tax revenues.

Table 6. Capacity to transform economic potential into revenues

\begin{tabular}{|c|c|c|c|c|c|c|c|c|c|}
\hline & $(1)$ & $(2)$ & $(3)$ & $(4)$ & (5) & (6) & (7) & (8) & (9) \\
\hline & OLS & $\begin{array}{c}\text { Pooled } \\
\text { OLS }\end{array}$ & $\begin{array}{c}\text { Region } \\
\text { FE }\end{array}$ & OLS & $\begin{array}{c}\text { Pooled } \\
\text { OLS }\end{array}$ & $\begin{array}{c}\text { Region } \\
\text { FE }\end{array}$ & OLS & $\begin{array}{c}\text { Pooled } \\
\text { OLS }\end{array}$ & $\begin{array}{c}\text { Region } \\
\text { FE }\end{array}$ \\
\hline Taxing autonomy & $\begin{array}{c}0.44 * * * \\
(0.04)\end{array}$ & $\begin{array}{c}0.43 * * * \\
(0.05)\end{array}$ & $\begin{array}{c}0.48 * * * \\
(0.02)\end{array}$ & & & & $\begin{array}{l}-0.01 \\
(0.19)\end{array}$ & $\begin{array}{l}0.06 \\
(0.17)\end{array}$ & $\begin{array}{c}0.23 * * * \\
(0.06)\end{array}$ \\
\hline Tax revenue & & & & $\begin{array}{c}0.66 \\
(0.35)\end{array}$ & $\begin{array}{c}0.68 \\
(0.37)\end{array}$ & $\begin{array}{c}0.75 * * \\
(0.28)\end{array}$ & $\begin{array}{l}-1.97 \\
(1.10)\end{array}$ & $\begin{array}{l}-1.54 \\
(0.87)\end{array}$ & $\begin{array}{c}-1.10^{* * *} \\
(0.37)\end{array}$ \\
\hline $\begin{array}{l}\text { Taxing autonomy } \times \\
\text { Tax revenue }\end{array}$ & & & & & & & $\begin{array}{l}0.89 * \\
(0.35)\end{array}$ & $\begin{array}{l}0.72 * \\
(0.29)\end{array}$ & $\begin{array}{c}0.55 * * * \\
(0.11)\end{array}$ \\
\hline Observations & 134 & 1021 & 1021 & 133 & 1013 & 1013 & 133 & 1013 & 1013 \\
\hline R-squared & 0.72 & 0.67 & 0.97 & 0.73 & 0.68 & 0.98 & 0.74 & 0.70 & 0.98 \\
\hline Region fixed-effects & $\mathrm{N}$ & $\mathrm{N}$ & $\mathrm{Y}$ & $\mathrm{N}$ & $\mathrm{N}$ & $\mathrm{Y}$ & $\mathrm{N}$ & $\mathrm{N}$ & $\mathrm{Y}$ \\
\hline
\end{tabular}

- The outcomes presented in Table 7 show that while greater spending autonomy is associated with higher debt levels, neither the size of sub-national expenditures nor an interaction term between spending autonomy and expenditure levels has a significant relation with debt levels.

Table 7. Control over spending

\begin{tabular}{|c|c|c|c|c|c|c|c|c|c|}
\hline & $(1)$ & $(2)$ & (3) & $(4)$ & $(5)$ & $(6)$ & $(7)$ & $(8)$ & $(9)$ \\
\hline & OLS & $\begin{array}{c}\text { Pooled } \\
\text { OLS }\end{array}$ & $\begin{array}{c}\text { Region } \\
\text { FE }\end{array}$ & OLS & $\begin{array}{c}\text { Pooled } \\
\text { OLS }\end{array}$ & $\begin{array}{c}\text { Region } \\
\text { FE }\end{array}$ & OLS & $\begin{array}{c}\text { Pooled } \\
\text { OLS }\end{array}$ & $\begin{array}{c}\text { Region } \\
\text { FE }\end{array}$ \\
\hline Spending autonomy & $\begin{array}{c}0.44 * * * \\
(0.04)\end{array}$ & $\begin{array}{c}0.43 * * * \\
(0.05)\end{array}$ & $\begin{array}{c}0.48 * * * \\
(0.01)\end{array}$ & & & & $\begin{array}{c}0.65 * * \\
(0.20)\end{array}$ & $\begin{array}{l}0.56^{*} \\
(0.26)\end{array}$ & $\begin{array}{c}0.286^{*} \\
(0.13)\end{array}$ \\
\hline Expenditure & & & & $\begin{array}{l}-2.53^{*} \\
(1.01)\end{array}$ & $\begin{array}{l}-2.01 \\
(1.65)\end{array}$ & $\begin{array}{c}0.71 \\
(1.22)\end{array}$ & $\begin{array}{c}3.47 \\
(8.58)\end{array}$ & $\begin{array}{c}2.32 \\
(7.76)\end{array}$ & $\begin{array}{l}-6.93 \\
(4.57)\end{array}$ \\
\hline $\begin{array}{l}\text { Spending autonomy } \\
\times \text { Expenditure } \\
\end{array}$ & & & & & & & $\begin{array}{l}-0.81 \\
(1.15)\end{array}$ & $\begin{array}{l}-0.60 \\
(1.25)\end{array}$ & $\begin{array}{r}1.09 \\
(0.64)\end{array}$ \\
\hline Observations & 134 & 1021 & 1021 & 134 & 1021 & 1021 & 134 & 1021 & 1021 \\
\hline R-squared & 0.72 & 0.67 & 0.97 & 0.74 & 0.68 & 0.97 & 0.74 & 0.68 & 0.97 \\
\hline Region fixed-effects & $\mathrm{N}$ & $\mathrm{N}$ & $\mathrm{Y}$ & $\mathrm{N}$ & $\mathrm{N}$ & $\mathrm{Y}$ & $\mathrm{N}$ & $\mathrm{N}$ & $\mathrm{Y}$ \\
\hline
\end{tabular}

27. Following de Mello's argument, the findings of the present paper would indicate that coordination problems arising from fiscal autonomy result in higher debt. 


\section{Political orientation of regional government and political alignment with the central government}

On the one side, the political orientation (left-right) of the regional government does not seem to have an impact on the levels of sub-national debt (Table 8). This is consistent with the literature that does not find clear evidence on this issue. On the other side, the coefficients in Table 8 suggest that regions where regional governments have the same political orientation than the central government have on average 3 percentage points higher debt levels (see Column 4-6). This effect is larger when the party in power at the regional level has a majority of parliamentary seats at the central level (compared to only being part of a ruling coalition), possibly as this allows further discretion in its decisions, as e.g. bailing-out regions.

Table 8. Political orientation and alignment between layers of government

\begin{tabular}{lccc|ccc|ccc}
\hline \hline & $(1)$ & $(2)$ & $(3)$ & $(4)$ & $(5)$ & $(6)$ & \multicolumn{2}{c}{$(7)$} & $(8)$ \\
& OLS & $\begin{array}{c}\text { Pooled } \\
\text { OLS }\end{array}$ & $\begin{array}{c}\text { Pooled } \\
\text { OLS }\end{array}$ & $\begin{array}{c}\text { OLS } \\
\text { Pooled } \\
\text { OLS }\end{array}$ & $\begin{array}{c}\text { Pooled } \\
\text { OLS }\end{array}$ & $\begin{array}{c}\text { OLS } \\
\text { Pooled } \\
\text { OLS }\end{array}$ & $\begin{array}{c}\text { Pooled } \\
\text { OLS }\end{array}$ \\
\hline & & & & & & & & & \\
Political orientation & 0.14 & 0.13 & 0.14 & & & & & \\
& $(0.09)$ & $(0.07)$ & $(0.08)$ & & & & & \\
Political alignment & & & & $0.35^{*}$ & $0.26^{* *}$ & $0.30^{*}$ & 0.09 & 0.07 & 0.07 \\
& & & & $(0.14)$ & $(0.08)$ & $(0.12)$ & $(0.17)$ & $(0.09)$ & $(0.11)$ \\
Political alignment $\times$ Majority & & & & & & & $0.68^{*}$ & $0.33^{* *}$ & $0.42^{*}$ \\
& & & & & & & $(0.28)$ & $(0.12)$ & $(0.18)$ \\
\hline Observations & 116 & 875 & 875 & 116 & 875 & 875 & 116 & 875 & 875 \\
R-squared & 0.72 & 0.65 & 0.66 & 0.72 & 0.66 & 0.67 & 0.74 & 0.66 & 0.67 \\
Region fixed-effects & $\mathrm{N}$ & $\mathrm{N}$ & $\mathrm{N}$ & $\mathrm{N}$ & $\mathrm{N}$ & $\mathrm{N}$ & $\mathrm{N}$ & $\mathrm{N}$ & $\mathrm{N}$ \\
Country $\times$ time FE & $\mathrm{N}$ & $\mathrm{N}$ & $\mathrm{Y}$ & $\mathrm{N}$ & $\mathrm{N}$ & $\mathrm{Y}$ & $\mathrm{N}$ & $\mathrm{N}$ & $\mathrm{Y}$ \\
\hline
\end{tabular}

Note: In all pooled and region fixed-effects regressions, errors are two-way clustered at the region and country-year level. Control variables as in Table 2 are included in all regressions, as are country fixed effects. In the pooled and region fixed-effects regressions, time fixed-effects are equally included. 


\section{HOW CENTRAL GOVERNMENT POLICIES AFFECT SUB-NATIONAL GOVERNMENTS}

This section examines how central government policies have affected SNGs in recent years, and tries to shed some light on the question whether the degree to which national governments have been handing down the burden of fiscal adjustment to sub-national levels has been even-handed. This discussion takes into account that margins for adjustment are generally smaller at the sub-national level. The analysis is mainly based on examples from the wave of fiscal adjustments in the wake of the 2007-09 global financial crisis. It also briefly looks at the impact of recent sovereign downgrades on regional governments.

\subsection{National consolidation plans can affect SNGs directly or indirectly}

Since 2009, many CGs have cut or frozen their transfers to SNGs, thereby directly affecting the fiscal position of the latter (Table 9). Ireland was one of the first countries reducing transfers to SNGs by $15 \%$ in 2009 and by $18 \%$ in $2010 .^{28}$ In 2010, France froze the main transfer to SNGs, the dotation générale de fonctionnement, until 2013. In Greece, central government transfers to SNGs increased, but at the same time new responsibilities were transferred to them, making it difficult to estimate the net change in transfers. In other countries (Belgium, Spain, Turkey) transfers fell automatically because the formulae are based on CG revenues, which decreased. Finally, in many countries some temporary transfers set by CGs in the framework of countercyclical spending policies to support SNGs during the global financial crisis came to an end in 2010 .

Table 9. Examples of discretionary changes in transfers (\% of SNGs revenues)

\begin{tabular}{|c|c|c|c|c|c|c|c|c|}
\cline { 2 - 8 } \multicolumn{1}{c|}{} & 2009 & 2010 & 2011 & 2012 & 2013 & \multicolumn{2}{|c|}{2014} & 2015 \\
\hline Estonia & $-5 \%$ & $0.15 \%$ & $0.65 \%$ & \multicolumn{5}{c|}{} \\
\hline Finland & & & \multicolumn{5}{c|}{$-1.52 \%$ over $2011-2015$} \\
\hline France & & & $-0.09 \%$ & $-0.26 \%$ & $-0.39 \%$ & $-0.43 \%$ & $-0.86 \%$ \\
\hline Greece & & & $0.05 \%$ & $1.48 \%$ & $-5.02 \%$ & $2.60 \%$ & \\
\hline Hungary & $-3.60 \%$ & $-1.50 \%$ & $-3.50 \%$ & & & & \\
\hline Italy & & & $-2.45 \%$ & $-3.17 \%$ & & & \\
\hline Ireland & & $3 \%$ & $4 \%$ & & & & \\
\hline Portugal & $-0.20 \%$ & $0.46 \%$ & $-1.33 \%$ & $-1.62 \%$ & & & \\
\hline Sweden & & $2.02 \%$ & $-1.04 \%$ & $-0.35 \%$ & & & \\
\hline UK* & $1.54 \%$ & $-1.11 \%$ & $-0.90 \%$ & $-0.90 \%$ & $-0.32 \%$ & & \\
\hline
\end{tabular}

Note: *-English Local Authorities

Source: Responses to OECD Fiscal Network questionnaire and OECD National Accounts.

In addition, some of the measures taken by CGs to reduce their budget deficits may indirectly affect SNG finances. Several countries increased the rate of shared taxes (such as VAT), thus benefiting SNGs (Austria, Canada, Czech Republic, Spain). In other cases, the CG increased tax allowances on shared taxes as a measure to stimulate the economy, thus reducing SNG revenues. ${ }^{29}$ Some national reforms, such as

28. The most significant reductions were in earmarked grants for infrastructure.

29. For example, in 2009 and 2010 the Portuguese CG increased the basic tax allowance on personal income tax and implemented an employee tax credit. Since $93.8 \%$ of personal income tax revenues are transferred to local governments, this measure significantly decreased the revenues of local governments. 
labour market, pension or social security reforms may also indirectly affect SNGs. ${ }^{30}$ In Spain, the CG implemented spending cuts which were applicable to all levels of government, the most remarkable being a general reduction of public wages of 5\%. In Greece, the "new unified salary framework" for the public sector (reduction in wages, increase in working time, increase in retirement age) also applied to SNGs. Reforms in the pension systems, and in particular in the retirement age, also affected SNGs (Australia, France, Spain and United Kingdom).

\subsection{SNGs are important actors in national consolidation plans}

Most countries require SNGs to participate in national fiscal consolidation efforts by introducing budget deficit targets and/or expenditure limits (Tables 10 and 11). For example, at the end of 2009, the Belgian CG and SNGs agreed on a target for 2009 and 2010 in order to limit deficits at the different level of government. For 2011 and 2012, budgetary objectives that are consistent with the Stability Programme were estimated, but no formal agreement was reached. However, these objectives were used as a reference by some of the SNGs. ${ }^{31}$ In Denmark, a target of zero growth in expenditure was set for municipalities in 2011 (unchanged levels in real terms compared to 2010). This target applied to the municipalities as a whole (i.e. average municipality expenditures).

Table 10. Sub-national government deficit objectives (as \% of GDP)

\begin{tabular}{|c|c|c|c|c|c|c|}
\cline { 2 - 7 } \multicolumn{1}{c|}{} & 2010 & 2011 & 2012 & 2013 & 2014 & 2015 \\
\hline Austria (state \& local) & & $-0.70 \%$ & $-0.50 \%$ & $-0.40 \%$ & $-0.30 \%$ & $-0.10 \%$ \\
\hline Belgium & $-0.7 \%$ & $-0.30 \%$ & $-0.40 \%$ & $0.00 \%$ & $0.10 \%$ & $0.10 \%$ \\
\hline Czech Republic & $-0.30 \%$ & $-0.50 \%$ & $-0.30 \%$ & $-0.20 \%$ & $0 \%$ & \\
\hline Poland & $-1.10 \%$ & & & & & \\
\hline Slovenia & $-4.80 \%$ & $-5.20 \%$ & $-3.70 \%$ & $-2.80 \%$ & $-1.90 \%$ & \\
\hline Spain (state level) & $-2.40 \%$ & $-1.30 \%$ & $-1.50 \%$ & $-0.70 \%$ & $-0.10 \%$ & \\
\hline Spain (local level) & $-0.60 \%$ & $-0.80 \%$ & $0 \%$ & $0 \%$ & $0 \%$ & \\
\hline Germany & \multicolumn{7}{|c|}{ Länder budgets must be structurally balanced as of 2020} \\
\hline
\end{tabular}

Source: Responses to OECD Fiscal Network questionnaire.

Table 11. Sub-national government expenditure reduction targets ( $\%$ of SNGs revenues)

\begin{tabular}{|c|c|c|c|c|c|c|}
\cline { 2 - 7 } \multicolumn{1}{c|}{} & 2010 & 2011 & 2012 & 2013 & 2014 & 2015 \\
\hline Slovak Republic & $-3.45 \%$ & $-3.56 \%$ & $-1.69 \%$ & $-3.15 \%$ & $-4.92 \%$ & \\
\hline United Kingdom* & & $-1.20 \%$ & $-0.87 \%$ & $-0.10 \%$ & $-0.68 \%$ & \\
\hline Belgium & & & $-0.31 \%$ & $-0.37 \%$ & $-0.37 \%$ & \\
\hline Greece & & & $-2.19 \%$ & $-3.65 \%$ & $-4.67 \%$ & $-6.59 \%$ \\
\hline
\end{tabular}

Note: *-English Local Authorities

Source: Responses to OECD Fiscal Network questionnaire and OECD National Accounts.

30. For example, the Czech amendment of the Labour Code which increased employment flexibility benefited SNGs.

31. After 2012, no specific fiscal target has been assigned to the regions and the communities. Belgium's 2011 Stability Programme only mentioned a global fiscal surplus to be reached by regions and municipalities, intended to compensate for a federal deficit of the same magnitude and thereby to reach a balanced budget for the whole country. 
In highly decentralised countries, CGs cannot always impose deficit targets on SNGs (Germany, although in the process of modifying this legislation; Switzerland) and, in many cases, CGs have little scope for action on municipalities which tend to be the agents of the regional tier of government. Nevertheless, CGs can try to influence SNG policies to encourage SNGs to return to fiscal balance in the medium term. This is the case in Canada, where all provinces and territories have announced plans to return to balance, with 12 out of 13 jurisdictions committed to doing so by 2014-15 at the latest.

Enforcement of fiscal rules has been tightened. In Italy, enforcement of the Internal Stability Pact was strengthened in 2011 by the introduction of a wide range of possible sanctions. For example, regions breaking the fiscal rules may not be allowed in the following year: $i$ ) to commit current expenditure (net of health) beyond the minimum commitment of the last three years; ii) to issue debts for investment purposes; iii) to hire new personnel; $i v$ ) to hire external managers; or $v$ ) to issue bonds and take out loans. Regions may even experience a reduction or suspension of financial transfers from the CG. Reporting rules have also been tightened, in particular for periods before elections. The audited financial statements of the regions must be published on their websites. If the results are not consistent with the Italian Internal Stability Pact, heavy sanctions may be imposed on the political officers, such as automatic disqualification from office and a ten-year interdiction from office. In Spain, where the autonomous communities missed their deficit target by a wide margin in 2011, the Minister of Finance proposed a gradual implementation of sanctions, ranging from retaining $C G$ transfers to imposing penalties, or ultimately imposing a restructuring plan. In Germany, the DATE constitutional amendment included the establishment of a Stability Council to monitor the budgetary developments at the federal and Länder levels, and introduced a federation-wide early warning system to prevent budgetary distress. The Stability Council replaces the former Financial Planning Council, and is composed of the federal ministers of finance and economic affairs, as well as the Länder ministers of finance.

In countries with some degree of substantial tax autonomy, SNGs often increased their own tax (raising the rate or broadening the base) and/or fees to meet fiscal targets (Australia, Belgium, Canada, Czech Republic, Denmark, Estonia, Finland, Greece, Hungary, Italy, Poland, Spain, and the United Kingdom). In Belgium, SNGs eliminated tax breaks that had been implemented in previous years. In 2010, the Flemish Community, in particular, abolished a tax cut that had been introduced in 2009 for all workers, aiming to increase the employment rate and increase the financial attractiveness of work ("job korting"). In Spain, autonomous communities and, to a lesser extent, local governments spontaneously increased some taxes, while also taking measures on the spending side. In particular, some autonomous communities increased the rates of, taxes on property transactions, personal income tax for high income earners, tax on retail sales of oil products and the duty on specific means of transport (tax on the registration of new vehicles, boats and planes). Some autonomous communities also established new environmental taxes. The movement towards higher taxes in local governments was less pronounced than for the autonomous communities. In this regard, an important measure will be the approval of new real estate values, which will provide higher receipts for the main local tax (tax on real estate property). Some countries also reported an increase in fees (Austrian municipalities, English local authorities, Greece).

When SNGs do not have tax autonomy, CGs often balance stricter deficit requirements by increasing the rates or shares of taxes allocated to SNGs, or by giving SNGs greater autonomy in setting the rates. In the Czech Republic, real estate tax rates (exclusive income of municipalities) were doubled under the consolidation measures approved at the end of 2009. The exemption from property tax for new buildings was cancelled in 2010. In addition, municipalities have been allowed to set local coefficients for real estate tax calculation since 2008 (real estate tax is calculated as a combination of surface, real estate tax rate, statutory coefficient and local coefficient). The revenues of municipalities were further augmented by increasing the rates and by extending the tax base for accommodation fees collected by them. 


\section{Box 1. The effect of sovereign downgrades on regional borrowing costs}

Rating agencies usually apply the "sovereign ceiling" rule, meaning that no issuer within a country can get a higher rating than the sovereign (in particular, SNGs cannot have a better rating than their central government). The justification for this rule is mainly that a shock strong enough to force the central government into default is most likely to also affect SNGs. As SNGs' room for manoeuvre is smaller than the central government's, these will most likely be in default. In most cases, the yields of central government bonds are indeed lower than those of SNGs. Exceptions are usually short-lived, generally reflecting noise in financial markets. The main exception is France, where the lle-deFrance and Paris SNGs enjoyed lower yields than the French government during most of the period from 2007 to 2012.

Sovereign downgrades can affect SNG bond yields in different ways: first, they may trigger a downgrade of the best rated SNGs (following the sovereign ceiling rule). Second, they may have a contagion effect through investor's behaviour, as these may be influenced by the sovereign downgrade in their evaluation of the SNG bond risk. Finally, to the degree that regional ratings or financial markets are taking into account bail-out expectations, the implicit guarantee from the sovereign may suffer with a CG downgrade.

Following the sovereign ceiling rule, rating agencies lowered the ratings of several SNGs, notably in France, Spain and Italy. In the case of Paris, for example, the announcement by S\&P made very clear that the downgrade was exclusively due to the prior downgrade of France, but that the intrinsic creditworthiness of Paris' bonds remained unchanged. The communiqué stated that: "Standard \& Poor's lowered its unsolicited long-term sovereign credit rating on the Republic of France to 'AA+' from 'AAA' on Jan. 13, 2012. Under our methodology for rating local and regional governments (LRGs) and their related sovereigns, we cap the rating on the City of Paris based on the long-term rating on France. Consequently, we are lowering our long-term issuer credit rating on Paris to 'AA+' from 'AAA'. [...] We continue to assess Paris' indicative credit level (ICL) at 'aaa "' (Standards and Poor's, 30 January 2012).32 In Italy, the downgrades of Rome and Umbria announced on 27 January 2012 were also the direct consequence of the sovereign downgrade by S\&P that occurred on 13 January 2012.

The effects of these sovereign downgrades differed. The French SNG downgrades (Paris, lle-de-France) did not affect the respective yields. In contrast, the downgrades of Rome and Umbria in the wake of the Italian downgrade did push the yields of these SNGs up, even though the downgrades had been expected by investors due to the sovereign ceiling rule. This may be considered as a case of vertical contagion, by re-focusing investor's attention on the difficulties faced by SNGs. Sovereign downgrades had little impact of SNG bond yields when they did not trigger downgrades in application of the sovereign ceiling rule.

Source: Vammalle, C. and C. Hulbert (2013), "Sub-national finances and fiscal consolidation: Walking on thin ice", OECD Regional Development Working Papers, No. 2013/02, OECD Publishing, doi: 10.1787/5k49m8cqkcf3-en.

Sub-national governments also cracked down on tax evasion to increase revenues. In Ireland, SNGs took initiatives to ensure that all owners of non-principal private residences were paying the appropriate charges. In Spain, autonomous communities developed instruments to reinforce co-operation between the different tax administrations to reduce tax evasion: exchange of information among administrations; sharing fiscal information to improve auditing; and developing software to improve auditing of selected taxpayers. Co-ordination bodies between the central tax administration and sub-national tax administrations also played an important role in fighting tax evasion, specifically in the building industry. In Greece, a 2010 law transferred the monitoring and enforcement of tax and fee collection to the Court of Auditors, who was seen to be better qualified for this task than political leaders at local level. ${ }^{33}$ The Italian central government tried to increase tax compliance by giving incentives to local governments to fight tax evasion, such as allowing them to keep up to $100 \%$ of the additional sums collected in their territories.

32. The "indicative credit level" (ICL) is a "shadow" rating, corresponding to the rating an issuer would get if there was no sovereign ceiling rule.

33. In Canada, Quebec - which collects all of its revenues - estimates that it will collect an additional CAD 1.2 billion per year by 2012-14 from measures to combat tax evasion and tax avoidance. 
In addition to attempting to raise their revenues, several SNGs were cutting expenditure and seeking efficiency gains (Canada, Estonia, United States). The US started consolidation policies early during the global financial crisis (2008) due to their constitutional obligation to have balanced budgets. They took measures such as cutting personnel and reducing health and social benefits, but also cut their transfers to lower tiers of government, thus creating a cascade effect in local governments of counties, cities, etc. (Vammalle et al., 2011). In Canada, provincial consolidation measures mostly consisted of wage restraint and a payroll freeze for the public service. ${ }^{34}$ In Estonia, the central government recommended that operating costs be frozen while allowing investment expenditure to grow, but could not impose this principle on SNGs. In Italy, the central government sought efficiency gains by encouraging municipal cooperation: it proposed a financial reward conditional on the setting-up of a "regional unit for purchasing" responsible for tender procedures for the provision of goods and services.

\subsection{The sharing of the consolidation burden across levels of governments}

Current consolidation strategies have affected governments at all layers. Across the OECD, the cost of the consolidation packages, however, has not been spread in the same way amongst the different levels of government. This leads to the question of whether the consolidation burden has been shared even-handedly across levels of government. More generally, the question arises of how much consolidation SNGs should implement. Their capacity to undertake the required adjustments is usually more limited, not least as key (social) spending generally accounts for a larger share of their spending. Unfortunately, determining the "even-handedness" of the consolidation process is a complex issue that at the moment only has partial and imperfect answers.

\subsubsection{Deficit reduction targets}

The ultimate welfare effects of uneven adjustments efforts are hard to predict as individual utility ultimately depends on total levels of taxes and public service provision. However, a perception that adjustment efforts are uneven could be a significant political factor working against the success of fiscal stabilisation attempts. One possibility to assess the even-handedness of adjustment efforts is by looking at the adjustment targets, e.g. on deficits or spending, set for each layer of government. When central governments have responsibility for establishing the targets for their sub-national governments, they could be "passing the buck" by requesting adjustments in excess of lower layers revenue capacity or expenditure responsibilities. However, examining the share of the adjustment effort of different levels of governments by itself brings little insight about even-handedness. To be meaningful, any comparison of the consolidation effort across different levels of government has to take into account the respective responsibilities, and the share of spending of the different levels of government. A reasonable proxy for that should be their share of total government spending. ${ }^{35}$ One possibility is therefore to compare the share of the planned adjustment effort of a certain level of government with its share in total government spending. ${ }^{36}$

34. According to projections in February 2012, the programme spending in 2011-12 was to increase by 3.1\%, well below the annual average growth of 6.3\% observed between 2000-01 and 2010-11. Most provinces also projected that their programme spending would grow by less than $3 \%$ per year throughout their forecast horizons.

35. More precisely, the share of deficit adjustment is the target of deficit decrease required to a certain level of government, expressed as a share of the total decrease targeted for the whole country (i.e. general government). The share of own revenues of this government is also expressed as a share of the general government revenues.

36. Excluding CG transfers to other levels of government. 
For four of the five countries for which data are available, the share of the post global financial crisis adjustment that sub-national governments are supposed to bear is somewhat below their sub-national share of spending, possibly reflecting their more limited space for adjustment. ${ }^{37}$ Yet, for one country the programmed share of sub-national adjustment would appear unusually large. These findings, however, should not be seen as final conclusions as actual adjustment efforts and outcomes may differ from initial plans. Also, availability of data may be correlated with the even-handedness of adjustments/ the generosity of CGs.

\subsubsection{Deficit reduction in practice}

While it is difficult to say much about how actual adjustment efforts have been shared so far, it is at least possible to look at the actual type and magnitude of the consolidation undertaken by the different layers of government in 2010. In this context, even-handedness would usually indicate that both national and sub-national governments should follow a common strategy, e.g. both of them should decrease spending. ${ }^{38}$ For the largest group of countries this indeed was the case in 2010, but in a fairly large group of countries CG spending (excluding transfers to lower levels of government) actually increased while SNG spending decreased. However, the interpretation of this finding should be done with some prudence. Responsibilities for social spending, for example, are distributed differently between levels of government across countries. Such spending is likely to increase in bad economic times, which may result in adjustment efforts at a given level of government not necessarily showing up in its spending outcomes. ${ }^{39}$ Finally, for actual 2010 deficit outcomes the picture was even more mixed. This is probably in some part due to differences in revenue collection efforts, as well as a reflection that sub-national and central government revenues differ in respect to their elasticity to economic activity.

\section{CONCLUSION}

This paper explores the question of whether central and sub-national governments have a tendency to "pass the buck" to the other level of government, a question particularly relevant in difficult financial times. The main conclusions of this paper are that while debt is in part explained by the debt servicing capacity of individual regions, moral hazard and bailout expectations also seem to play an important role in sub-national fiscal policy. High debt levels driven by such expectations may then later result in demands for bailouts. Inversely, while central governments usually seem to push down part of fiscal adjustment efforts to the sub-national level, the jury is still out on whether they have done this in an even or uneven fashion in recent years. Once sufficient data have become available, it would hence be interesting to explore this issue in more depth. Also, further advances in understanding to what degree and under which conditions fiscal behaviour at the sub-national level is driven by moral hazard would greatly benefit from more extensive information at the level of individual sub-national entities. Such information would also, beyond the subject treated here, open up plentiful new possibilities for advancing the understanding of fiscal relations and sub-national finances.

37. First, the revenue base of SNGs is smaller and SNGs' autonomy to increase revenues is usually limited, with little or no power over tax rates or tax bases, and high reliance on transfers. Second, an important share of SNG expenditure is mandatory and/or difficult to cut, because reductions entail high social and political costs. On average, SNGs spend $50 \%$ of their budgets on education, health and social protection.

38. There could obviously be circumstances that would justify a digression from that simple rule. However, in general one would expect significant fiscal adjustment efforts to be joint exercises across levels of government.

39. In principle, it would be preferable to undertake such an analysis with cyclically adjusted fiscal data, but those data are currently unavailable for regional fiscal variables. 


\section{REFERENCES}

Alesina, A., Cohen, G. and Roubini, N. (1993), "Electoral business cycle in industrial democracies", European Journal of Political Economy, 9, 1-23.

Arulampalam W., Dasgupta, S., Dhillon, A. and Dutta, B. (2009), "Electoral goals and center state transfers: a theoretical model and empirical evidence from India," Journal of Development Economics, 88, 103-119.

Bartolini, D. and Santolini, R. (2012), "Political yardstick competition among Italian municipalities on spending decisions," The Annals of Regional Science, 49(1), 213-235.

Baskaran, T. (2010), "On the link between fiscal decentralization and public debt in OECD countries," Public Choice, 145, 351-378.

Blais, A., Blake, D. and Dion, S. (1993), "Do parties make a difference? Parties and the size of government in liberal democracies", American Journal of Political Science, 37: 40-62.

Blöchliger, H. (2011), "Fiscal consolidation at the sub-central government level", paper prepared for the annual meeting of the OECD Network on Fiscal Relations across Levels of Government, Paris, November 2011, COM/CTPA/ECO/GOV(2011)4.

Blöchliger, H., Charbit, C., Piñero Campos, J.-M. and Vammalle, C. (2010), "Sub-central governments and the economic crisis: Impact and policy responses", OECD Economics Department Working Papers, No. 752, OECD Publishing, doi: 10.1787/5kml6xq5bgwc-en.

Blöchliger, H., and King, D. (2006), "Fiscal autonomy of sub-central governments", OECD Network on Fiscal Relations across Levels of Government WP No. 2.

Bohn, H. and Inman, R.P. (1996), "Balanced budget rules and public deficits: Evidence from the U.S. States", NBER Working Paper 5533.

Bordignon, M. and Turati, G. (2009), "Bailing out expectations and public health expenditure", Journal of Health Economics, 28, 305-321.

Borge, L-E., Falch, T. and Tovmo, P. (2008), "Public sector efficiency: The roles of political and budgetary institutions, fiscal capacity and democratic participation", Public Choice, 136, 475-495.

Borrelli, S. and Royed, T. (1995), "Government strength and budget deficits in advanced democracies", European Journal of Political Research, 28(2), 225-260.

de Mello, L. Jr. (2000), "Fiscal decentralization and intergovernmental fiscal relations: A cross-country analysis", World Development, 28(2), 365-380.

Eichengreen, B. and von Hagen, J. (1996), "Federalism, fiscal restraints, and European Monetary Union", American Economic Review 86: 134-39.

Escolano, J., Eyraud, L., Moreno Badia, M., Sarnes, J., and Tuladhar, A. (2012), "Fiscal performance, institutional design and decentralization in European Union countries," IMF WP/12/45. 
Freitag, M., and Vatter, A. (2008), "Decentralization and fiscal discipline in sub-national governments: Evidence from the Swiss federal system," Publius: The Journal of Federalism, 38(2), 272-294.

Grembi, V., Nannicini, T. and Troiano, U. (2011), "Policy responses to fiscal restraints: A difference-indiscontinuities design,” Working Papers 397, IGIER, Bocconi University.

Hodrick, J. and Prescott, E.C. (1997), "Postwar U.S. business cycles: An empirical investigation," Journal of Money, Credit and Banking, 29(1).

Khemani, S. (2002), "Federal politics and budget deficits: Evidence from the states of India," World Bank Policy Research Working Paper 2915.

Lewis, B.D. (2003), "Local Government Borrowing and Repayment in Indonesia: Does Fiscal Capacity Matter?," World Development, 31(6), 1047-10 63.

Mau, N.-J. (2011), "Prevention of local government unsustainable behaviour: some Danish experience", paper presented at the 2011 Copenhagen Workshop on "Normative Frameworks of Decentralisation and Intergovernmental Fiscal Relations".

Nordhaus, W. D. (1975), “The political business cycle”. Review of Economic Studies 42 (2), 169-190.

Poterba J. (1994), "State responses to fiscal crisis: The effects of budgetary institutions and politics", Journal of Political Economy, 102(4),799-821.

Ravn, M.O. and Uhlig, H. (2002), "On adjusting the Hodrick-Prescott filter for the frequency of observations", The Review of Economics and Statistics, 84(2), 371-380.

Rodden, J. (2002), "The dilemma of fiscal federalism: Grants and fiscal performance around the world," American Journal of Political Science, 46(3), 670-687.

Roubini, N. and Sachs, J. (1989a), "Political and economic determinants of budget deficits in the industrial democracies", European Economic Review, 33, 903-938.

Roubini, N. and Sachs, J. (1989b), "Government spending and budget deficits in the industrial countries", Economic Policy, 12, 100-132.

Seitz, H. (2000), "Fiscal policy, deficits and politics of subnational governments: The case of the German Länder", Public Choice, 102: 183-218.

Sorribas-Navarro, P. (2011), "Bailouts in a fiscal federal system: Evidence from Spain," European Journal of Political Economy, Elsevier, vol. 27(1), 154-170.

Tovmo, P. (2007), "Budgetary procedures and deficits in Norwegian local governments", Economics of Governance, 8, 37-49.

von Hagen, J., Bordignon, M., Dahlberg, M., Grewal, B.S., Petterson, P. and Seitz, H. (2000), "Subnational government bailouts in OECD countries: Four case studies", Working Paper R-399, InterAmerican Development Bank Research Network, Washington D.C.

Vammalle, C. and C. Hulbert (2013), "Sub-national finances and fiscal consolidation: Walking on thin ice”, OECD Regional Development Working Papers, No. 2013/02, OECD Publishing, doi: $10.1787 / 5 k 49 m 8 c q k c f 3-e n$. 
Vammalle, C., Allain-Dupré, D. and Gaillard, N. (2011), “A Sub-central government perspective on fiscal policy in a tight fiscal environment" in OECD/KIPF, Institutional and Financial Relations across Levels of Government, OECD Publishing, Paris, doi: 10.1787/9789264167001-3-en.

Wildasin, D.E. (1997), "Externalities and bailouts. Hard and soft budget constraints in intergovernmental fiscal relations", World Bank Policy Working Paper No. 1843. 


\section{Annex}

Table A1. Capacity to transform economic potential into revenues (non-linear effect)

\begin{tabular}{|c|c|c|c|}
\hline & $(1)$ & $(2)$ & $(3)$ \\
\hline & OLS & $\begin{array}{c}\text { Pooled } \\
\text { OLS }\end{array}$ & $\begin{array}{c}\text { Region } \\
\text { FE }\end{array}$ \\
\hline \multirow[t]{2}{*}{ Taxing autonomy } & $1.34 * * *$ & $1.34 * * *$ & $0.56 * * *$ \\
\hline & $(0.152)$ & $(0.211)$ & $(0.069)$ \\
\hline \multirow[t]{2}{*}{ Taxing autonomy ${ }^{2}$} & $-0.23 * * *$ & $-0.23 * * *$ & -0.02 \\
\hline & $(0.040)$ & $(0.057)$ & $(0.020)$ \\
\hline Observations & 134 & 1021 & 1021 \\
\hline R-squared & 0.72 & 0.67 & 0.97 \\
\hline Region fixed-effects & $\mathrm{N}$ & $\mathrm{N}$ & $\mathrm{Y}$ \\
\hline
\end{tabular}

Note: In all pooled and region fixed-effects regressions, errors are two-way clustered at the region and country-year level. Control variables as in Table 2 are included in all regressions, as are country fixed effects. In the pooled and region fixed-effect regressions, time fixed-effects are equally included. 